\title{
LEVEL II SCOUR ANALYSIS FOR BRIDGE 5 (BRNETH00020005) on TOWN HIGHWAY 2, crossing EAST PEACHAM BROOK, BARNET, VERMONT
}

\section{Open-File Report 98-263}

Prepared in cooperation with

VERMONT AGENCY OF TRANSPORTATION and

FEDERAL HIGHWAY ADMINISTRATION

U.S. Department of the Interior

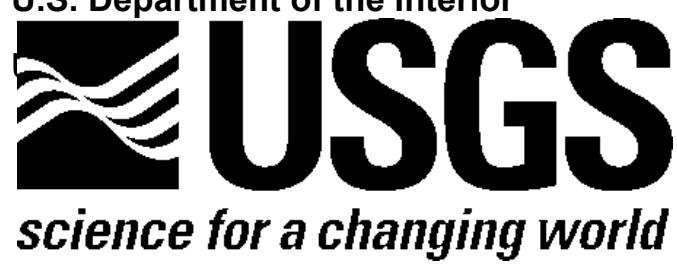




\section{LEVEL II SCOUR ANALYSIS FOR BRIDGE 5 (BRNETH00020005) on TOWN HIGHWAY 2, crossing EAST PEACHAM BROOK, BARNET, VERMONT}

By MICHAEL A. IVANOFF AND LAURA MEDALIE

U.S. Geological Survey Open-File Report 98-263

Prepared in cooperation with

VERMONT AGENCY OF TRANSPORTATION

and

FEDERAL HIGHWAY ADMINISTRATION 


\title{
U.S. DEPARTMENT OF THE INTERIOR BRUCE BABBITT, Secretary
}

\author{
U.S. GEOLOGICAL SURVEY
}

Thomas J. Casadevall, Acting Director

For additional information write to:

District Chief

U.S. Geological Survey 361 Commerce Way

Pembroke, NH 03275-3718
Copies of this report may be purchased from:

U.S. Geological Survey

Branch of Information Services

Open-File Reports Unit

Box 25286

Denver, CO 80225-0286 


\section{CONTENTS}

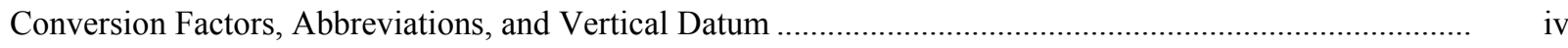

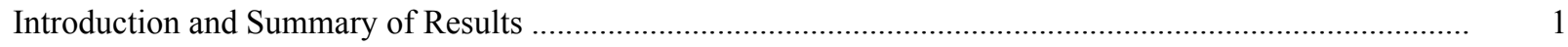

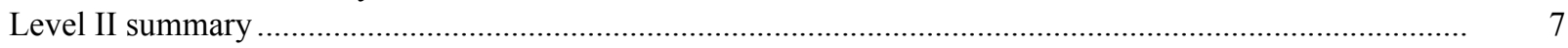

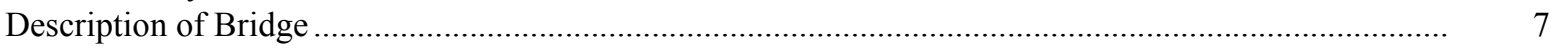

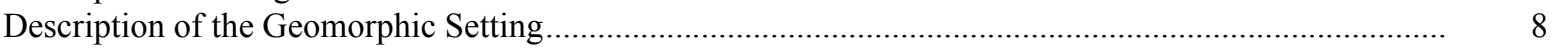

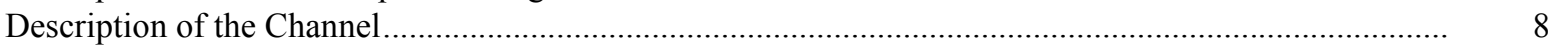

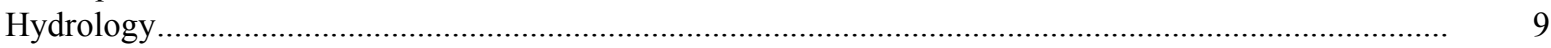

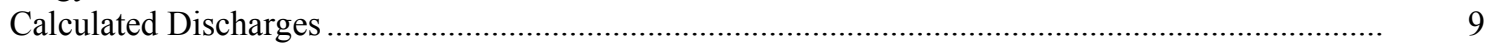

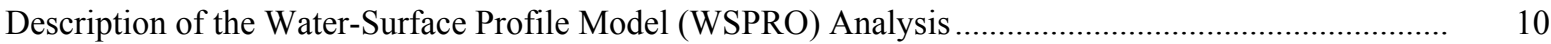

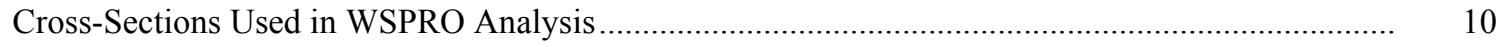

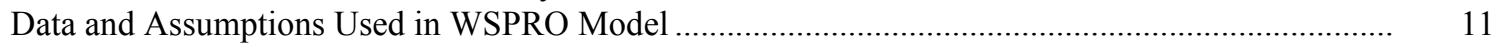

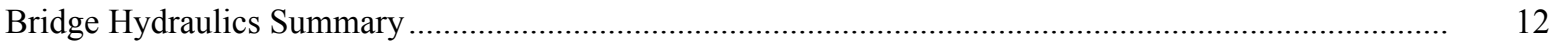

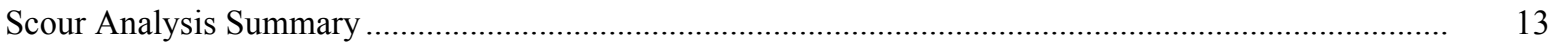

Special Conditions or Assumptions Made in Scour Analysis ................................................... 13

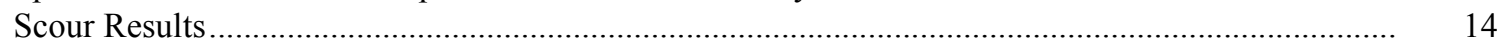

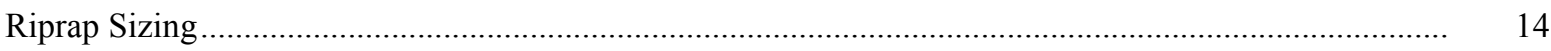

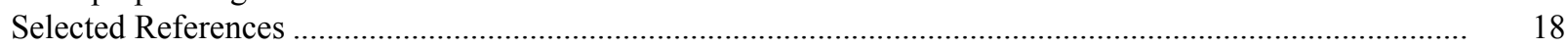

Appendices:

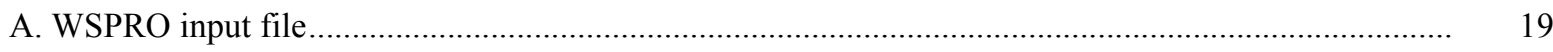

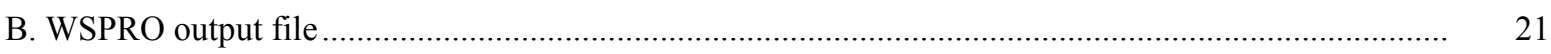

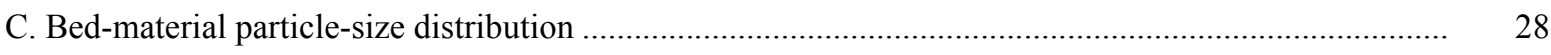

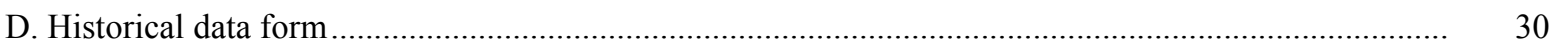

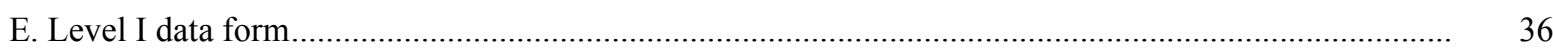

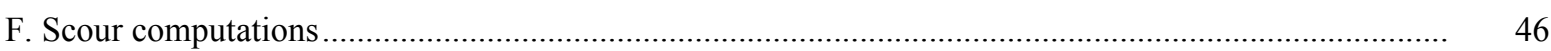

\section{FIGURES}

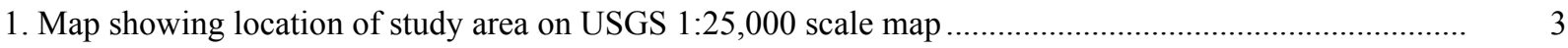

2. Map showing location of study area on Vermont Agency of Transportation town

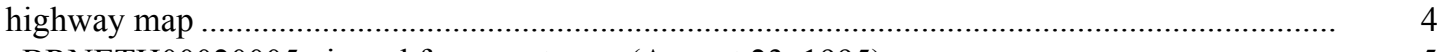

3. Structure BRNETH00020005 viewed from upstream (August 23, 1995) ....................................... 5

4. Downstream channel viewed from structure BRNETH00020005 (August 23, 1995)............................. 5

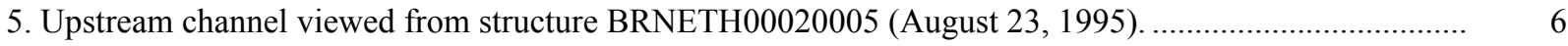

6. Structure BRNETH00020005 viewed from downstream (August 23, 1995).......................................... 6

7. Water-surface profiles for the 100- and 500-year discharges at structure

BRNETH00020005 on Town Highway 2, crossing East Peacham Brook,

Barnet, Vermont.

8. Scour elevations for the 100- and 500-year discharges at structure

BRNETH00020005 on Town Highway 2, crossing East Peacham Brook,

Barnet, Vermont.

\section{TABLES}

1. Remaining footing/pile depth at abutments for the 100-year discharge at structure

BRNETH00020005 on Town Highway 2, crossing East Peacham Brook,

Barnet, Vermont.

2. Remaining footing/pile depth at abutments for the 500-year discharge at structure BRNETH00020005 on Town Highway 2, crossing East Peacham Brook, Barnet, Vermont. 


\begin{tabular}{|c|c|c|}
\hline Multiply & By & To obtain \\
\hline \multicolumn{3}{|c|}{ Length } \\
\hline inch (in.) & 25.4 & millimeter (mm) \\
\hline foot $(\mathrm{ft})$ & 0.3048 & meter $(\mathrm{m})$ \\
\hline mile (mi) & 1.609 & kilometer (km) \\
\hline \multicolumn{3}{|c|}{ Slope } \\
\hline foot per mile ( $\mathrm{ft} / \mathrm{mi})$ & 0.1894 & meter per kilometer $(\mathrm{m} / \mathrm{km})$ \\
\hline \multicolumn{3}{|c|}{ Area } \\
\hline square mile $\left(\mathrm{mi}^{2}\right)$ & 2.590 & square kilometer $\left(\mathrm{km}^{2}\right)$ \\
\hline \multicolumn{3}{|c|}{ Volume } \\
\hline cubic foot $\left(\mathrm{ft}^{3}\right)$ & $\begin{array}{l}0.02832 \\
\text { Velocity and Flow }\end{array}$ & cubic meter $\left(\mathrm{m}^{3}\right)$ \\
\hline foot per second (ft/s) & 0.3048 & meter per second $(\mathrm{m} / \mathrm{s})$ \\
\hline cubic foot per second $\left(\mathrm{ft}^{3} / \mathrm{s}\right)$ & 0.02832 & cubic meter per second $\left(\mathrm{m}^{3} / \mathrm{s}\right)$ \\
\hline $\begin{array}{l}\text { cubic foot per second per } \\
\text { square mile } \\
{\left[\left(\mathrm{ft}^{3} / \mathrm{s}\right) / \mathrm{mi}^{2}\right]}\end{array}$ & 0.01093 & $\begin{array}{l}\text { cubic meter per } \\
\text { second per square } \\
\text { kilometer }\left[\left(\mathrm{m}^{3} / \mathrm{s}\right) / \mathrm{km}^{2}\right]\end{array}$ \\
\hline
\end{tabular}

\section{OTHER ABBREVIATIONS}

\begin{tabular}{|c|c|c|c|}
\hline $\mathrm{BF}$ & bank full & LWW & left wingwall \\
\hline $\mathrm{cfs}$ & cubic feet per second & Max & maximum \\
\hline $\mathrm{D}_{50}$ & median diameter of bed material & $\mathrm{MC}$ & main channel \\
\hline DS & downstream & RAB & right abutment \\
\hline elev. & elevation & RABUT & face of right abutment \\
\hline $\mathrm{f} / \mathrm{p}$ & flood plain & $\mathrm{RB}$ & right bank \\
\hline $\mathrm{ft}^{2}$ & square feet & ROB & right overbank \\
\hline $\mathrm{ft} / \mathrm{ft}$ & feet per foot & RWW & right wingwall \\
\hline FEMA & Federal Emergency Management Agency & $\mathrm{TH}$ & town highway \\
\hline FHWA & Federal Highway Administration & UB & under bridge \\
\hline JCT & junction & US & upstream \\
\hline LAB & left abutment & USGS & United States Geological Survey \\
\hline LABUT & face of left abutment & VTAOT & Vermont Agency of Transportation \\
\hline LB & left bank & WSPRO & water-surface profile model \\
\hline LOB & left overbank & $\mathrm{yr}$ & year \\
\hline
\end{tabular}

In this report, the words "right" and "left" refer to directions that would be reported by an observer facing downstream. Sea level: In this report, "sea level" refers to the National Geodetic Vertical Datum of 1929-- a geodetic datum derived from a general adjustment of the first-order level nets of the United States and Canada, formerly called Sea Level Datum of 1929.

In the appendices, the above abbreviations may be combined. For example, USLB would represent upstream left bank. 


\title{
LEVEL II SCOUR ANALYSIS FOR BRIDGE 5 (BRNETH00020005) ON TOWN HIGHWAY 2, CROSSING EAST PEACHAM BROOK, BARNET, VERMONT
}

\author{
By Michael A. Ivanoff and Laura Medalie
}

\section{INTRODUCTION AND SUMMARY OF RESULTS}

This report provides the results of a detailed Level II analysis of scour potential at structure BRNETH00020005 on Town Highway 2 crossing East Peacham Brook, Barnet, Vermont (figures 1-8). A Level II study is a basic engineering analysis of the site, including a quantitative analysis of stream stability and scour (Federal Highway Administration, 1993). Results of a Level I scour investigation also are included in appendix E of this report. A Level I investigation provides a qualitative geomorphic characterization of the study site. Information on the bridge, gleaned from Vermont Agency of Transportation (VTAOT) files, was compiled prior to conducting Level I and Level II analyses and is found in appendix D.

The site is in the New England Upland section of the New England physiographic province in east-central Vermont. The $15.9-\mathrm{mi}^{2}$ drainage area is in a predominantly rural and forested basin. In the vicinity of the study site, the surface cover is forest.

In the study area, East Peacham Brook has an incised, sinuous channel with a slope of approximately $0.004 \mathrm{ft} / \mathrm{ft}$, an average channel top width of $60 \mathrm{ft}$ and an average bank height of $4 \mathrm{ft}$. The channel bed material ranges from gravel to boulder with a median grain size $\left(\mathrm{D}_{50}\right)$ of $63.5 \mathrm{~mm}(0.208 \mathrm{ft})$. The geomorphic assessment at the time of the Level I and Level II site visit on August 23, 1995, indicated that the reach was laterally unstable with moderate fluvial erosion along the banks and trees have fallen into the channel.

The Town Highway 2 crossing of East Peacham Brook is a 49-ft-long, two-lane bridge consisting of one 46-foot steel-beam span (Vermont Agency of Transportation, written communication, March 16, 1995). The opening length of the structure parallel to the bridge face is $44.5 \mathrm{ft}$. The bridge is supported by vertical, concrete abutments with spill-through embankments. The channel is skewed approximately zero degrees to the opening, and the opening-skew-to-roadway is also zero degrees.

The only scour protection measure at the site was type- 2 stone fill (less than 36 inches diameter) along the left and right abutments that form spill-through embankments. Additional details describing conditions at the site are included in the Level II Summary and appendices $\mathrm{D}$ and $\mathrm{E}$. 
Scour depths and recommended rock rip-rap sizes were computed using the general guidelines described in Hydraulic Engineering Circular 18 (Richardson and others, 1995) for the 100- and 500-year discharges. In addition, the incipient roadway-overtopping discharge is determined and analyzed as another potential worst-case scour scenario. Total scour at a highway crossing is comprised of three components: 1) long-term streambed degradation; 2) contraction scour (due to accelerated flow caused by a reduction in flow area at a bridge) and; 3 ) local scour (caused by accelerated flow around piers and abutments). Total scour is the sum of the three components. Equations are available to compute depths for contraction and local scour and a summary of the results of these computations follows.

Contraction scour for all modelled flows ranged from 0.5 to $2.4 \mathrm{ft}$. The worst-case contraction scour occurred at the 500-year discharge. Left abutment scour ranged from 11.6 to $12.4 \mathrm{ft}$. Right abutment scour ranged from 6.2 to $6.7 \mathrm{ft}$. The worst-case abutment scour occurred at the 500-year discharge. Additional information on scour depths and depths to armoring are included in the section titled "Scour Results". Scoured-streambed elevations, based on the calculated scour depths, are presented in tables 1 and 2. A cross-section of the scour computed at the bridge is presented in figure 8. Scour depths were calculated assuming an infinite depth of erosive material and a homogeneous particle-size distribution.

It is generally accepted that the Froehlich equation (abutment scour) gives "excessively conservative estimates of scour depths" (Richardson and others, 1995, p. 47). Usually, computed scour depths are evaluated in combination with other information including (but not limited to) historical performance during flood events, the geomorphic stability assessment, existing scour protection measures, and the results of the hydraulic analyses. Therefore, scour depths adopted by VTAOT may differ from the computed values documented herein. 


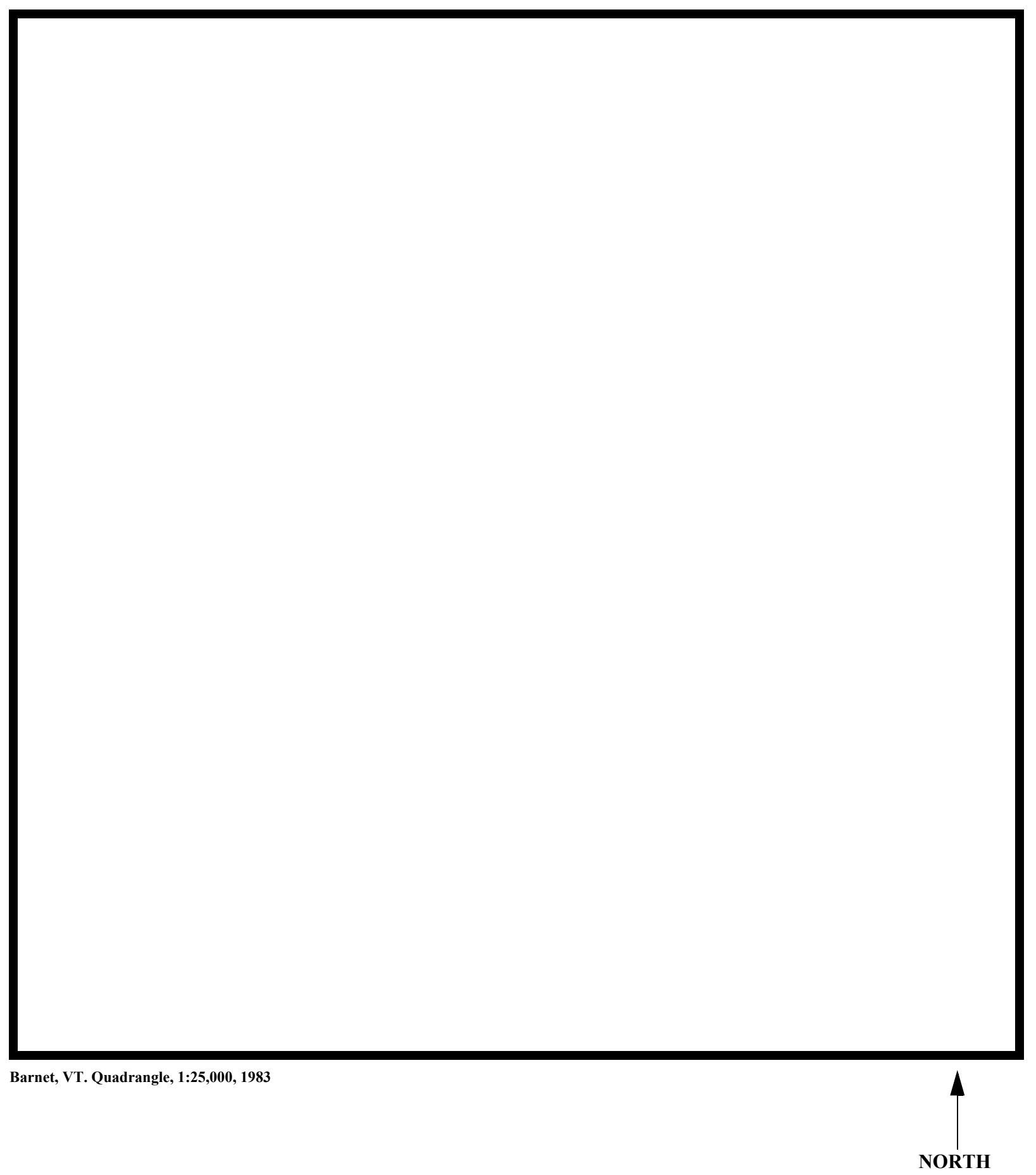

Figure 1. Location of study area on USGS 1:25,000 scale map. 
Figure 2. Location of study area on Vermont Agency of Transportation town highway map. 

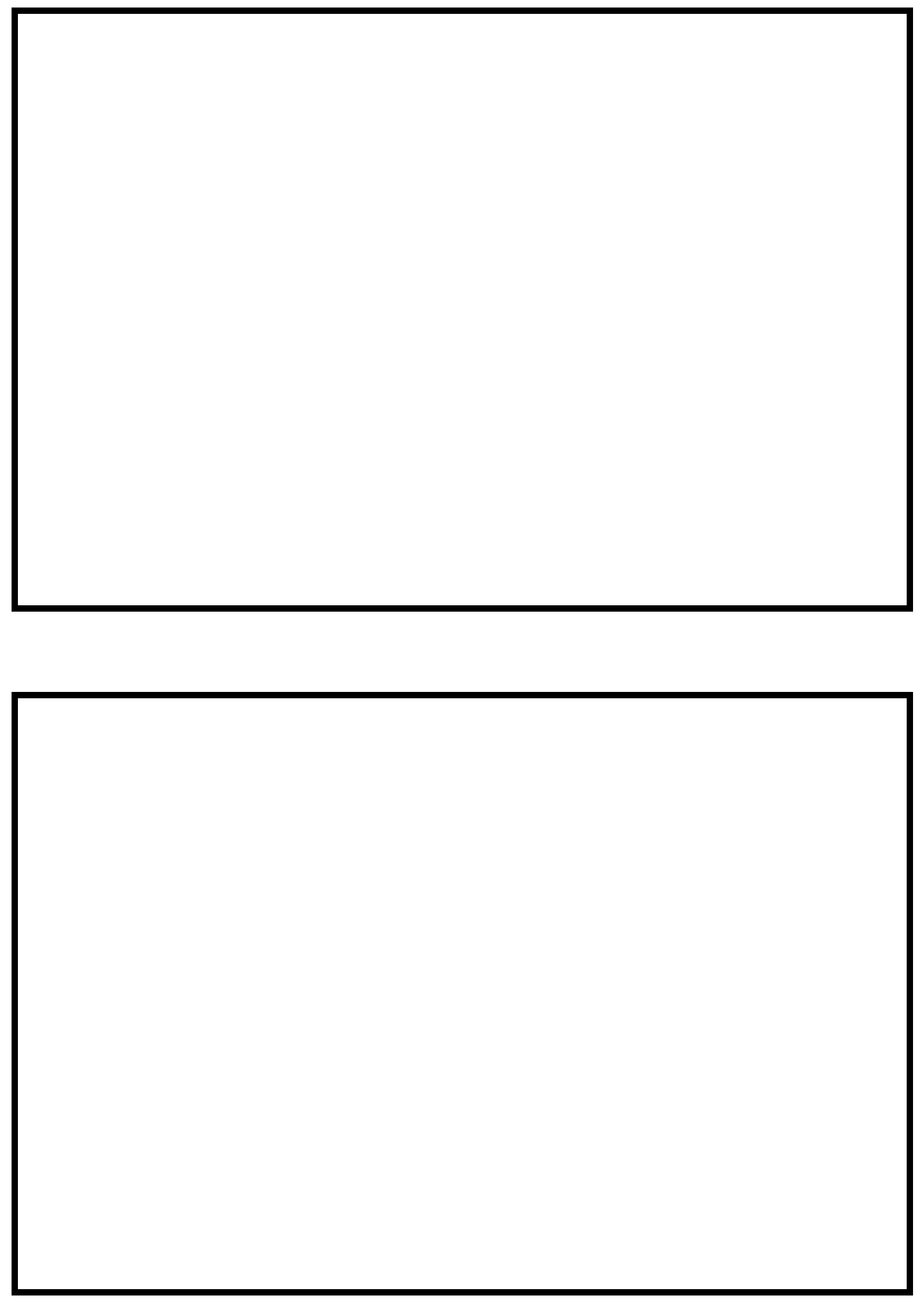

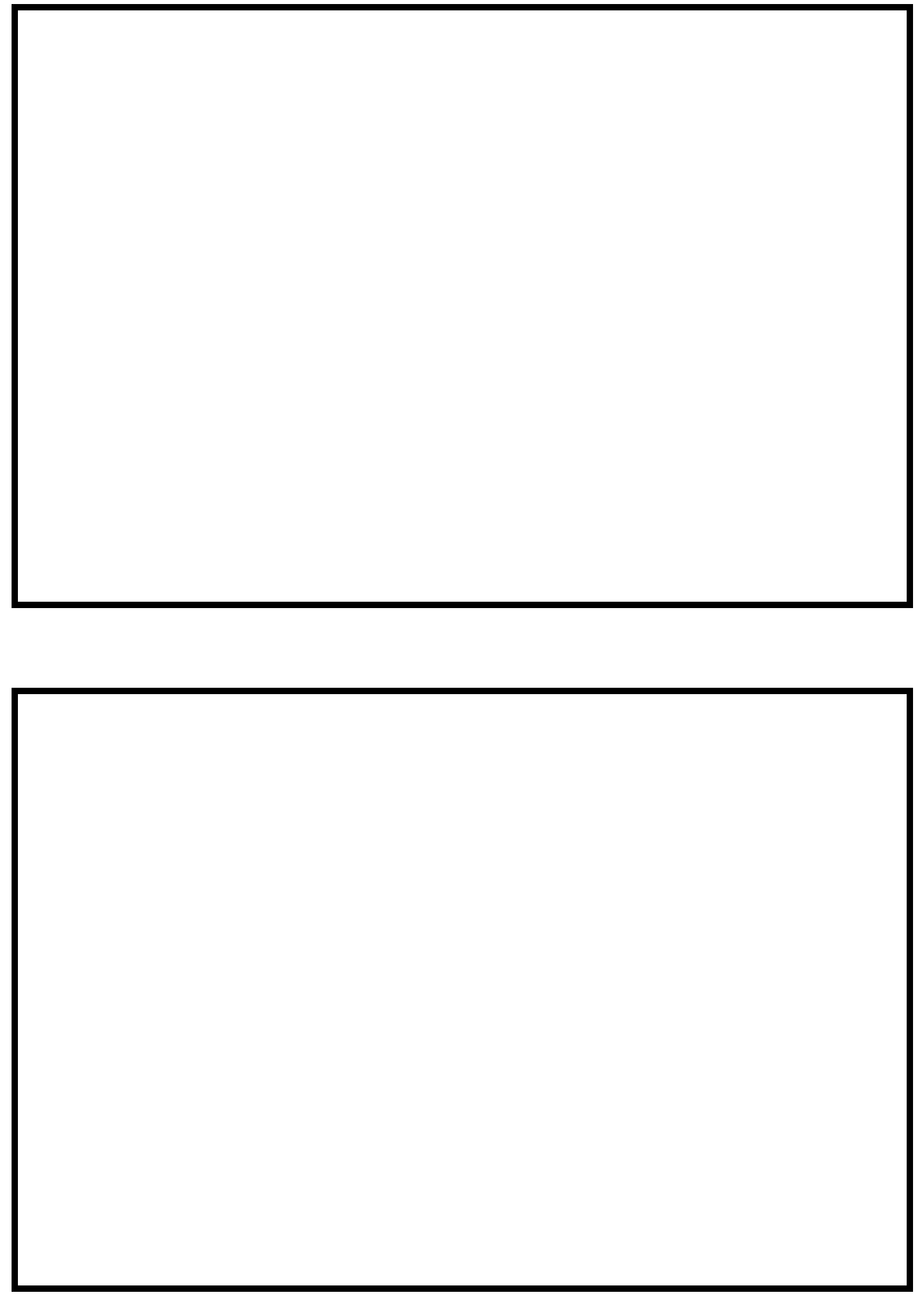


\section{LEVEL II SUMMARY}

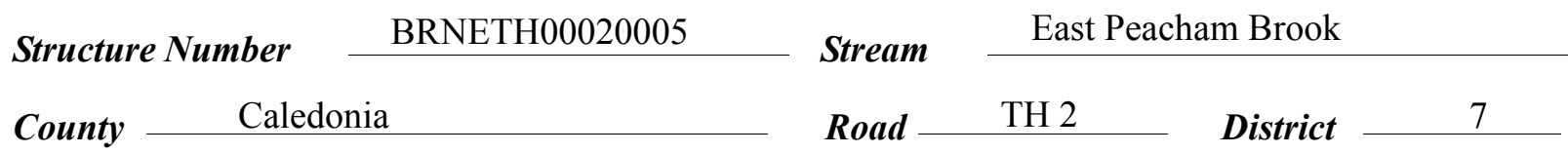

\section{Description of Bridge}

Bridge length $\stackrel{49.0}{ } \boldsymbol{f t} \quad$ Bridge width $\frac{26.0}{f t} \quad$ Max span length $\stackrel{46.0}{f t}$ Alignment of bridge to road (on curve or straight)

Abutment type Vertical, concrete

Stone fill on abutment?

$$
\text { Yes }
$$

\section{Embankment type \\ Drto of incnortion} Straight Type-2, along the base of the left and right abutments extending

around the upstream and downstream wingwall ends forming spill-through embankments

Abutments are concrete. The stone blocks at the base of the abutments form spill-through slopes.

No

$$
--
$$

\section{No}

There is

Is bridge skewed to flood flow according to a 'survey?

Angle

severe channel bend in the upstream and downstream reach over $200 \mathrm{ft}$ from the bridge.

$8 / 23 / 95$

Debris accumulation on bridge at time of Level I or Level II site visit:

$$
\begin{gathered}
\text { Date af insnortion } \\
0
\end{gathered} \quad \begin{gathered}
\text { Percent of ahmunal } \\
\text { blocked inortzontatly }
\end{gathered}
$$

\section{Percent of ahannon blocked nortzontatly}$$
95
$$

Level I

Level II

leaning over the channel upstream.

Potential for debris
0
Percent o: $8 / 23 /$
blocked verticatty 0

None as of $8 / 23 / 95$.

Doscriho any, foaturos noar ar at tho hridoo that mav, affort flou, (includo ahsorvation dato) 


\section{Description of the Geomorphic Setting}

General topography The channel is located within a moderate relief valley with steep valley walls on both sides.

Geomorphic conditions at bridge site: downstream (DS), upstream (US)

Date of inspection $\quad 8 / 23 / 95$

DS left: $\quad$ Steep channel bank to a moderately sloped overbank.

DS right: $\quad$ Steep channel bank to a moderately sloped overbank.

US left: $\quad$ Steep channel bank to a moderately sloped overbank.

US right: $\quad$ Steep valley wall.

\section{Description of the Channel}

$\begin{array}{llll}\text { Average top width } & 60 & \text { Average depth } & \frac{4}{\text { Gravel/Cobbles }} \\ & \text { Gravel / Cobbles }\end{array}$

Predominant bed material Bank material Sinuous but stable

with semi-allúvial channel boundaries.

$8 / 23 / 95$

Vegetative co 1 Trees and brušh.

DS left: $\quad$ Trees and brush.

DS right: $\quad$ Trees and brush.

US left: $\quad$ Trees and brush.

US right:

No

Do banks appear stable? There is moderate fluvial erosion along the banks and trees haye fallen into the channel.

None 8/23/95.

Describe any obstructions in channel and date of observation. 


\section{Hydrology}

Drainage area $\frac{15.9}{\boldsymbol{m i}^{2}}$

Percentage of drainage area in physiographic provinces: (approximate)

Physiographic province/section New England/New England Upland
Percent of drainage area 100

Is drainage area considered rural or urban? — Rural _ Describe any significant urbanization:

Is there a USGS gage on the stream of interest?

No

USGS gage description

USGS gage number

Gage drainage area $\mathrm{mi}^{2}$

Is there a lake/p

\section{Calculated Discharges $\quad \underline{2,940}$ \\ 2,330 $f t^{3} / s$ \\ Q500 $\quad \mathrm{ft}^{3} / \mathrm{s}$}

The 100- and 500-year discharges were obtained

from the median of several flood freguency curves based on empirical methods (Benson, 1962;

Johnson and Tasker, 1974; FHWA, 1983; Potter, 1957a\&b; Talbot, 1887). Each curve was extended graphically to the 500-year event. 


\section{Description of the Water-Surface Profile Model (WSPRO) Analysis}

Datum for WSPRO analysis (USGS survey, sea level, VTAOT plans)

USGS survey

Datum tie between USGS survey and VTAOT plans $\quad$ Subtract $695 \mathrm{ft}$ from the USGS

arbitrary survey datum to obtain the datum used within the VTAOT plans.

Description of reference marks used to determine USGS datum. $\quad$ RM1 is a chiseled X on

top of the downstream end of the left abutment (elev. $798.93 \mathrm{ft}$, arbitrary survey datum). RM2 is

a chiseled $\mathrm{X}$ on top of the upstream end of the right abutment (elev. $798.79 \mathrm{ft}$, arbitrary survey

datum).

Cross-Sections Used in WSPRO Analysis

\begin{tabular}{|c|c|c|c|}
\hline${ }^{1}$ Cross-section & $\begin{array}{c}\text { Section } \\
\text { Reference } \\
\text { Distance } \\
\text { (SRD) in feet }\end{array}$ & $\begin{array}{c}{ }^{2} \text { Cross-section } \\
\text { development }\end{array}$ & Comments \\
\hline EXITX & -31 & 1 & Exit section \\
\hline FULLV & 0 & 2 & $\begin{array}{l}\text { Downstream Full-valley } \\
\text { section (Templated from } \\
\text { EXITX) }\end{array}$ \\
\hline BRIDG & 0 & 1 & Bridge section \\
\hline RDWAY & 13 & 1 & Road Grade section \\
\hline APPRO & 72 & 1 & Approach section \\
\hline
\end{tabular}

${ }^{1}$ For location of cross-sections see plan-view sketch included with Level I field form, Appendix E.

For more detail on how cross-sections were developed see WSPRO input file. 


\section{Data and Assumptions Used in WSPRO Model}

Hydraulic analyses of the reach were done by use of the Federal Highway Administration's WSPRO step-backwater computer program (Shearman and others, 1986, and Shearman, 1990). The analyses reported herein reflect conditions existing at the site at the time of the study. Furthermore, in the development of the model it was necessary to assume no accumulation of debris or ice at the site. Results of the hydraulic model are presented in the Bridge Hydraulic Summary, appendix B, and figure 7.

Channel roughness factors (Manning's “ $n$ ”) used in the hydraulic model were estimated using field inspections at each cross section following the general guidelines described by Arcement and Schneider (1989). Final adjustments to the values were made during the modelling of the reach. The channel " $n$ " value for the reach was 0.055 , and the overbank " $n$ " value was 0.075 .

Normal depth at the exit section (EXITX) was assumed as the starting water surface. This depth was computed by use of the slope-conveyance method outlined in the user's manual for WSPRO (Shearman, 1990). The slope used was $0.0036 \mathrm{ft} / \mathrm{ft}$, which was estimated from surveyed points downstream of the bridge.

The approach section (APPRO) was surveyed one bridge length upstream of the upstream face as recommended by Shearman and others (1986). This location provides a consistent method for determining scour variables. 


\section{Bridge Hydraulics Summary}

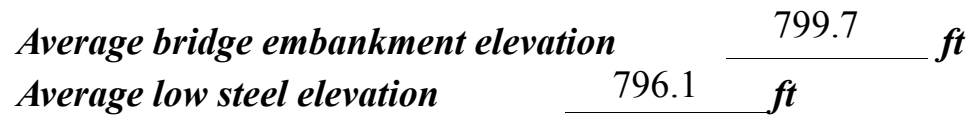

\begin{tabular}{|c|c|c|c|c|}
\hline \multirow{2}{*}{\multicolumn{3}{|c|}{$\begin{array}{l}\text { 100-year discharge } \\
\text { Water-surface elevation in bridge opening }\end{array}$}} & \multirow[b]{2}{*}{$796.2 f$} & \multirow[b]{2}{*}{$f t$} \\
\hline & & & & \\
\hline Road overtopping? & No & \multicolumn{2}{|c|}{ Discharge over road } & \multirow[t]{2}{*}{--} \\
\hline \multicolumn{2}{|c|}{ Area of flow in bridge opening } & \multicolumn{2}{|c|}{$f t^{2}$} & \\
\hline Average velocity in $b$ & openin & 9.0 & $f t / s$ & \\
\hline Maximum WSPRC & locity & & 11.1 & $f t / s$ \\
\hline
\end{tabular}

Water-surface elevation at Approach section with bridge Water-surface elevation at Approach section without bridge 798.3 Amount of backwater caused by bridge

1.9 it

500-year discharge $\quad 2,940 \quad \mathrm{ft}^{3} / \mathrm{s}$

Water-surface elevation in bridge opening $796.2 \boldsymbol{f t}$

Road overtopping? ___ Yes Discharge over road __ $136 \mathrm{ft}^{3} / \mathrm{s}$

Area of flow in bridge opening $\quad 254 \quad \mathrm{ft}^{2}$

Average velocity in bridge opening $11.1 \mathrm{ft} / \mathrm{s}$

Maximum WSPRO tube velocity at bridge 13.4 's

Water-surface elevation at Approach section with bridge

Water-surface elevation at Approach section without bridge

Amount of backwater caused by bridge $3.0, t$

800.1

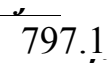

Incipient overtopping discharge $\quad 2,570 \quad \mathrm{ft}^{3} / \mathrm{s}$

Water-surface elevation in bridge opening $796.2 \quad t$

Area of flow in bridge opening

Average velocity in bridge opening

$254 \mathrm{ft}^{2}$

Maximum WSPRO tube velocity at bridge

9.9 $f t / s$

Water-surface elevation at Approach section with bridge Water-surface elevation at Approach section without bridge Amount of backwater caused by bridge $\quad 2.3$ it

799.0

796.7 


\section{Scour Analysis Summary}

\section{Special Conditions or Assumptions Made in Scour Analysis}

Scour depths were computed using the general guidelines described in Hydraulic Engineering Circular 18 (Richardson and others, 1995). Scour depths were calculated assuming an infinite depth of erosive material and a homogeneous particle-size distribution. The results of the 100-year and 500-year scour analysis are presented in tables 1 and 2 and a graph of the scour depths is presented in figure 8 .

At this site, the 100-year, 500-year, and incipient roadway-overtopping discharges resulted in submerged orifice flow. Contraction scour at bridges with orifice flow is best estimated by use of the Chang pressure-flow scour equation (oral communication, J. Sterling Jones, October 4, 1996). Thus, contraction scour for these discharges (Figure 8 and Tables 1 and 2) was computed by use of the Chang equation (Richardson and others, 1995, p. 145146). For comparison, estimates of contraction scour also were computed by use of the Laursen clear-water contraction scour equation (Richardson and others, 1995, p. 32, equation 20) and the Umbrell pressure-flow equation (Richardson and others, 1995, p. 144) and are presented in appendix F. The streambed armoring depths computed suggest that armoring will not limit the depth of contraction scour.

Abutment scour was computed by use of the Froehlich equation (Richardson and others, 1995, p. 48, equation 28). Variables for the Froehlich equation include the Froude number of the flow approaching the embankments, the length of the embankment blocking flow, and the depth of flow approaching the embankment less any roadway overtopping.

Because the influence of scour processes on the spill-through embankment material is uncertain, the scour depth at the vertical concrete abutment walls is unknown. Therefore, the total scour depth computed at the toe of each embankment was applied to the entire embankment, as shown in figure 8.

The length to depth ratio of the embankment blocking flow exceeded 25 for the left abutment. Although the HIRE equation (Richardson and others, 1993, p. 50, equation 25) is generally applicable when this ratio exceeds 25 , the results from the HIRE equation were not used. Hydraulic Engineering Circular 18 recommends that the field conditions be similar to those from which the HIRE equation was derived (Richardson and others, 1993). Since the equation was developed from U. S. Army Corps of Engineers' data for spur dikes in the Mississippi River, the HIRE equation was determined to be non-applicable to the narrow, incised, upland valley at this site. 


\section{Scour Results}

\section{0-yr discharge 500-yr discharge}

Contraction scour:

(Scour depths in feet)

Main channel

Live-bed scour

Clear-water scour

Depth to armoring

Left overbank

Right overbank

Local scour:

Abutment scour

Left abutment

11.6

12.4

12.2

$6.2-$

$6.7-$

$6.5-$

Right abutment

Pier scour

Pier 1

Pier 2

Pier 3

\section{Abutments:}

Left abutment

Right abutment

Piers:

Pier 1

Pier 2

overtopping discharge 


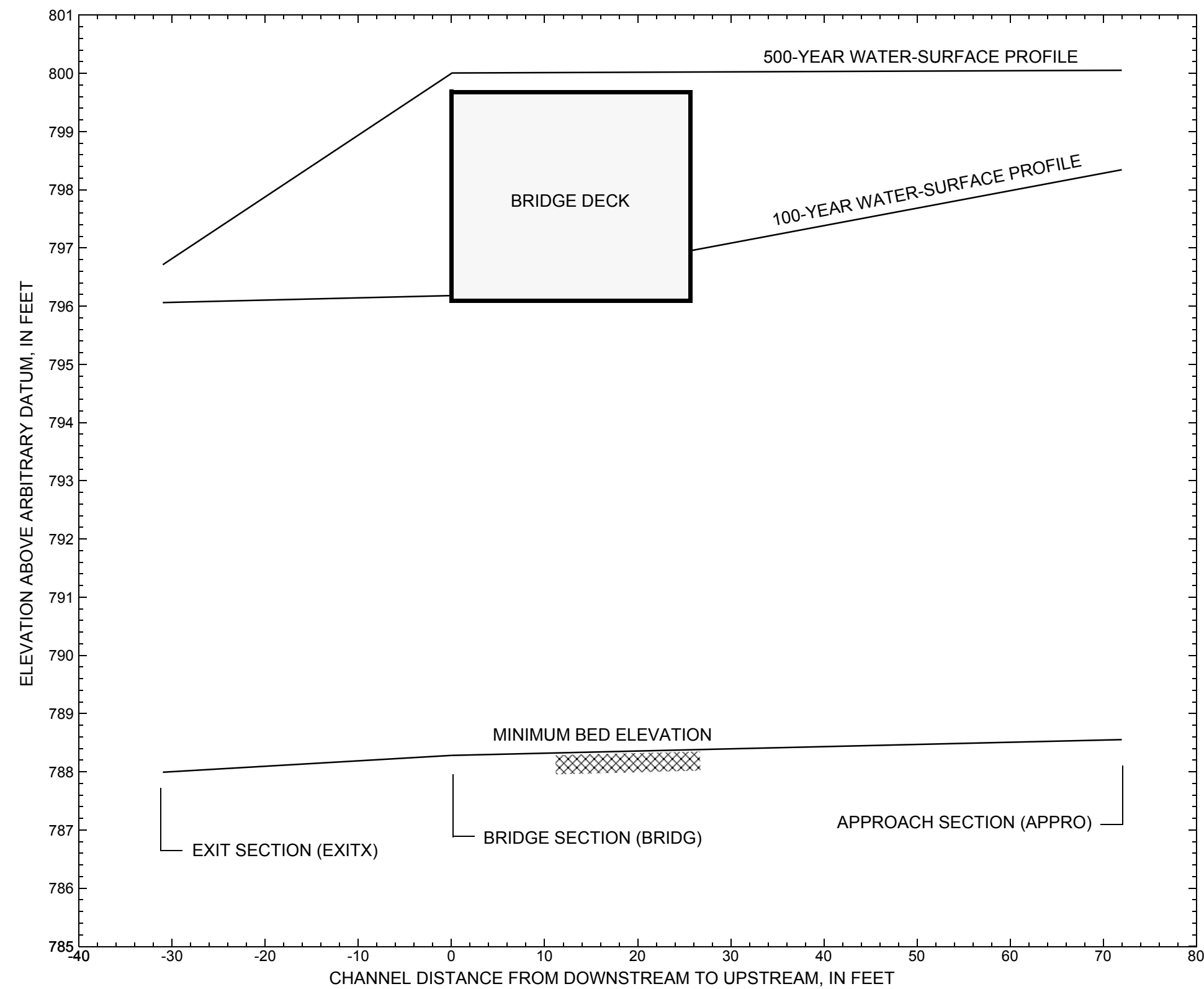

Figure 7. Water-surface profiles for the 100- and 500-year discharges at structure BRNETH00020005 on Town Highway 2, crossing East Peacham Brook, Barnet, Vermont. 


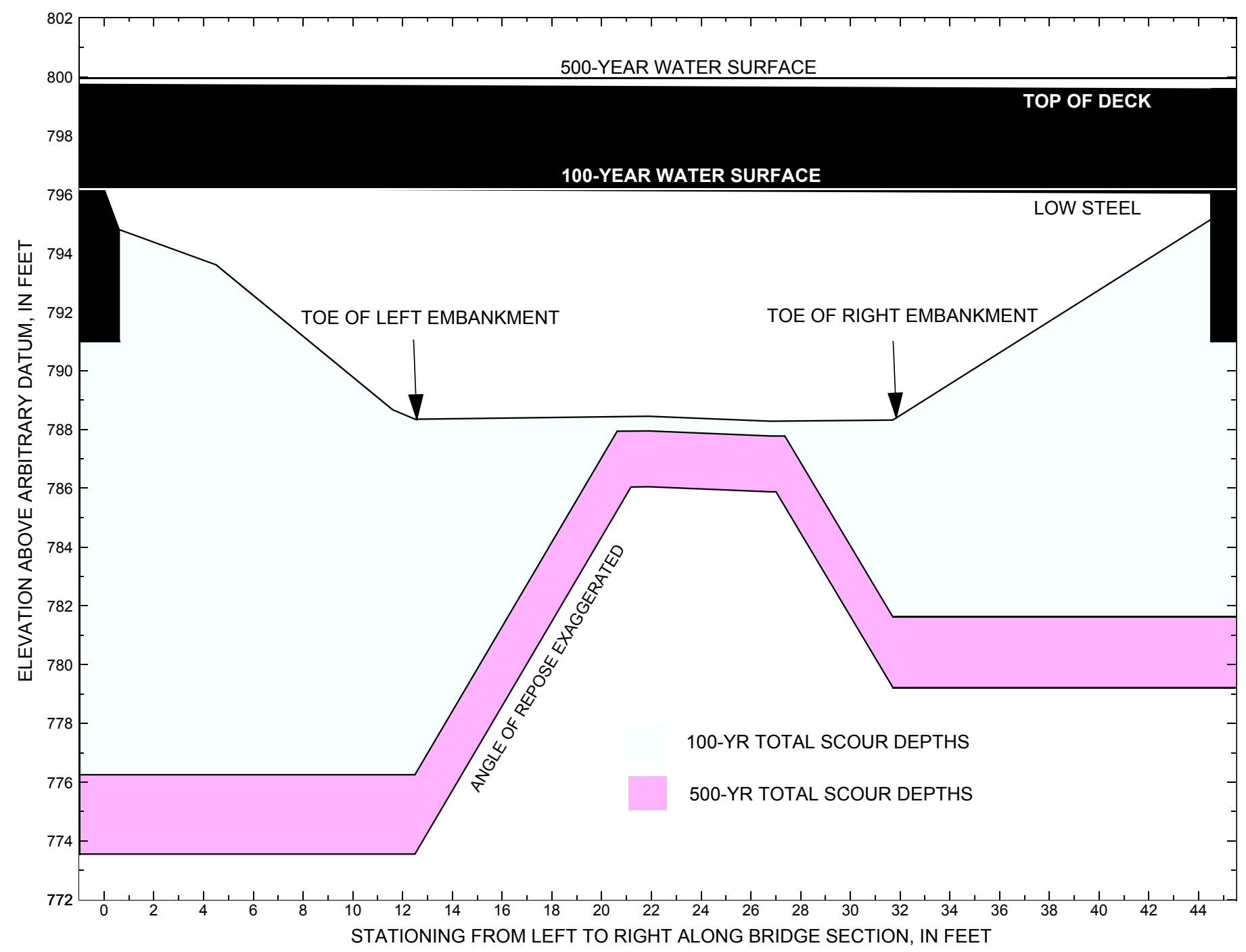

Figure 8. Scour elevations for the 100- and 500-year discharges at structure BRNETH00020005 on Town Highway 2, crossing East Peacham Brook, Barnet, Vermont. 


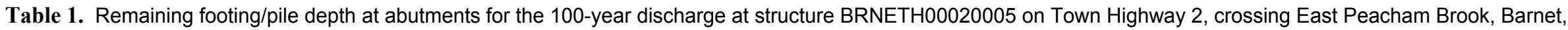
Vermont.

[VTAOT, Vermont Agency of Transportation; --,no data]

\begin{tabular}{|c|c|c|c|c|c|c|c|c|c|c|c|}
\hline Description & Station ${ }^{1}$ & $\begin{array}{c}\text { VTAOT } \\
\text { minimum } \\
\text { bridge seat } \\
\text { elevation } \\
\text { (feet) }\end{array}$ & $\begin{array}{l}\text { Surveyed } \\
\text { minimum } \\
\text { low-chord } \\
\text { elevation } \\
\text { (feet) }\end{array}$ & $\begin{array}{c}\text { Bottom of } \\
\text { footing } \\
\text { elevation } \\
\text { (feet) }\end{array}$ & $\begin{array}{c}\text { Channel } \\
\text { elevation at } \\
\text { abutment/ } \\
\text { pier }^{2} \\
\text { (feet) }\end{array}$ & $\begin{array}{l}\text { Contraction } \\
\text { scour depth } \\
\text { (feet) }\end{array}$ & $\begin{array}{l}\text { Abutment } \\
\text { scour } \\
\text { depth } \\
\text { (feet) }\end{array}$ & $\begin{array}{l}\text { Pier } \\
\text { scour } \\
\text { depth } \\
\text { (feet) }\end{array}$ & $\begin{array}{l}\text { Depth of } \\
\text { total scour } \\
\text { (feet) }\end{array}$ & $\begin{array}{c}\text { Elevation of } \\
\text { scour }^{2} \\
\text { (feet) }\end{array}$ & $\begin{array}{c}\text { Remaining } \\
\text { footing/pile } \\
\text { depth } \\
\text { (feet) }\end{array}$ \\
\hline \multicolumn{12}{|c|}{100 -year discharge is 2,330 cubic-feet per second } \\
\hline Left abutment & 0.0 & 100.7 & 796.2 & 791.0 & 794.8 & -- & -- & -- & -- & -- & -14.7 \\
\hline $\begin{array}{c}\text { Toe of left } \\
\text { embankment }\end{array}$ & 12.5 & -- & -- & -- & 788.4 & 0.5 & 11.6 & -- & 12.1 & 776.3 & -- \\
\hline $\begin{array}{l}\text { Toe of right } \\
\text { embankment }\end{array}$ & 31.7 & -- & -- & -- & 788.3 & 0.5 & 6.2 & -- & 6.7 & 781.6 & -- \\
\hline Right abutment & 44.5 & 100.5 & 796.0 & 791.0 & 795.2 & -- & -- & -- & -- & -- & -9.4 \\
\hline
\end{tabular}

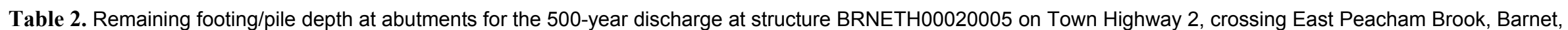
Vermont.

[VTAOT, Vermont Agency of Transportation; --, no data]

\begin{tabular}{|c|c|c|c|c|c|c|c|c|c|c|c|}
\hline Description & Station ${ }^{1}$ & $\begin{array}{l}\text { VTAOT } \\
\text { minimum } \\
\text { bridge seat } \\
\text { elevation } \\
\text { (feet) }\end{array}$ & $\begin{array}{c}\text { Surveyed } \\
\text { minimum } \\
\text { low-chord } \\
\text { elevation } \\
\text { (feet) }\end{array}$ & $\begin{array}{c}\text { Bottom of } \\
\text { footing } \\
\text { elevation } \\
\text { (feet) }\end{array}$ & $\begin{array}{c}\text { Channel } \\
\text { elevation at } \\
\text { abutment/ } \\
\text { pier }^{2} \\
\text { (feet) }\end{array}$ & $\begin{array}{l}\text { Contraction } \\
\text { scour depth } \\
\text { (feet) }\end{array}$ & $\begin{array}{l}\text { Abutment } \\
\text { scour } \\
\text { depth } \\
\text { (feet) }\end{array}$ & $\begin{array}{l}\text { Pier } \\
\text { scour } \\
\text { depth } \\
\text { (feet) }\end{array}$ & $\begin{array}{l}\text { Depth of } \\
\text { total scour } \\
\text { (feet) }\end{array}$ & $\begin{array}{c}\text { Elevation of } \\
\text { scour }^{2} \\
\text { (feet) }\end{array}$ & $\begin{array}{c}\text { Remaining } \\
\text { footing/pile } \\
\text { depth } \\
\text { (feet) }\end{array}$ \\
\hline \multicolumn{12}{|c|}{500 -year discharge is 2,940 cubic-feet per second } \\
\hline Left abutment & 0.0 & 100.7 & 796.2 & 791.0 & 794.8 & -- & -- & -- & -- & -- & -17.4 \\
\hline $\begin{array}{c}\text { Toe of left } \\
\text { embankment }\end{array}$ & 12.5 & -- & -- & -- & 788.4 & 2.4 & 12.4 & -- & 14.8 & 773.6 & -- \\
\hline $\begin{array}{l}\text { Toe of right } \\
\text { embankment }\end{array}$ & 31.7 & -- & -- & -- & 788.3 & 2.4 & 6.7 & -- & 9.1 & 779.2 & -- \\
\hline Right abutment & 44.5 & 100.5 & 796.0 & 791.0 & 795.2 & -- & -- & -- & -- & -- & -11.8 \\
\hline
\end{tabular}

1.Measured along the face of the most constricting side of the bridge.

2.Arbitrary datum for this study. 


\section{SELECTED REFERENCES}

Arcement, G.J., Jr., and Schneider, V.R., 1989, Guide for selecting Manning's roughness coefficients for natural channels and flood plains: U.S. Geological Survey Water-Supply Paper 2339, 38 p.

Barnes, H.H., Jr., 1967, Roughness characteristics of natural channels: U.S. Geological Survey Water-Supply Paper 1849,213 p.

Benson, M. A., 1962, Factors Influencing the Occurrence of Floods in a Humid Region of Diverse Terrain: U.S. Geological Survey WaterSupply Paper 1580-B, 64 p.

Brown, S.A. and Clyde, E.S., 1989, Design of riprap revetment: Federal Highway Administration Hydraulic Engineering Circular No. 11, Publication FHWA-IP-89-016, 156 p.

Federal Highway Administration, 1983, Runoff estimates for small watersheds and development of sound design: Federal Highway Administration Report FHWA-RD-77-158.

Federal Highway Administration, 1993, Stream Stability and Scour at Highway Bridges: Participant Workbook: Federal Highway Administration Report FHWA-HI-91-011.

Froehlich, D.C., 1989, Local scour at bridge abutments in Ports, M.A., ed., Hydraulic Engineering--Proceedings of the 1989 National Conference on Hydraulic Engineering: New York, American Society of Civil Engineers, p. 13-18.

Hayes, D.C.,1993, Site selection and collection of bridge-scour data in Delaware, Maryland, and Virginia: U.S. Geological Survey WaterResources Investigation Report 93-4017, 23 p.

Interagency Advisory Committee on Water Data, 1982, Guidelines for determining flood flow frequency: U.S. Geological Survey, Bulletin 17B of the Hydrology Subcommittee, 190 p.

Johnson, C.G. and Tasker, G.D.,1974, Progress report on flood magnitude and frequency of Vermont streams: U.S. Geological Survey OpenFile Report 74-130, 37 p.

Lagasse, P.F., Schall, J.D., Johnson, F., Richardson, E.V., Chang, F., 1995, Stream Stability at Highway Structures: Federal Highway Administration Hydraulic Engineering Circular No. 20, Publication FHWA-IP-90-014, 144 p.

Laursen, E.M., 1960, Scour at bridge crossings: Journal of the Hydraulics Division, American Society of Civil Engineers, v. 86, no. HY2, p. 39-53.

Potter, W. D., 1957a, Peak rates of runoff in the Adirondack, White Mountains, and Maine woods area, Bureau of Public Roads

Potter, W. D., 1957b, Peak rates of runoff in the New England Hill and Lowland area, Bureau of Public Roads

Richardson, E.V. and Davis, S.R., 1995, Evaluating scour at bridges: Federal Highway Administration Hydraulic Engineering Circular No. 18, Publication FHWA-IP-90-017, 204 p.

Richardson, E.V., Simons, D.B., and Julien, P.Y., 1990, Highways in the river environment: Federal Highway Administration Publication FHWA-HI-90-016.

Ritter, D.F., 1984, Process Geomorphology: W.C. Brown Co., Debuque, Iowa, 603 p.

Shearman, J.O., 1990, User's manual for WSPRO--a computer model for water surface profile computations: Federal Highway Administration Publication FHWA-IP-89-027, 187 p.

Shearman, J.O., Kirby, W.H., Schneider, V.R., and Flippo, H.N., 1986, Bridge waterways analysis model; research report: Federal Highway Administration Publication FHWA-RD-86-108, 112 p.

Talbot, A.N., 1887, The determination of water-way for bridges and culverts.

U.S. Geological Survey, 1983, Barnet, Vermont 7.5 X 15 Minute Series quadrangle map: U.S. Geological Survey Topographic Maps, Scale $1: 25,000$. 


\section{APPENDIX A: \\ WSPRO INPUT FILE}




\section{WSPRO INPUT FILE}

*

XS

GR

GR

GR

GR

GR

*

$\mathrm{N}$

SA

*

XS

*

*

BR

GR

GR

GR

*

CD

$\mathrm{N}$

*

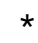

XR

GR

GR

GR

*

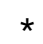

AS

GR

GR

GR

GR

*

$\mathrm{N}$

SA

*

HP 1 BRIDG

HP 2 BRIDG

HP 1 APPRO

HP 2 APPRO

*

HP 1 BRIDG

HP 2 BRIDG

HP 2 RDWAY

HP 1 APPRO
U.S. Geological Survey WSPRO Input File brne005.wsp Hydraulic analysis for structure BRNETH00020005 Date: 16-SEP-97 Bridge 5 on Town Highway 2 over East Peacham Brook Barnet, VT by MAI

$\begin{array}{lllllllllllllllllllll}6 & 29 & 30 & 552 & 553 & 551 & 5 & 16 & 17 & 13 & 3 & * & 15 & 14 & 23 & 21 & 11 & 12 & 4 & 7 & 3\end{array}$ $\begin{array}{lll}2330.0 & 2940.0 & 2570.0 \\ 0.0036 & 0.0036 & 0.0036\end{array}$

$\operatorname{EXITX} \quad-31$

$$
\begin{array}{rrrr}
-377.5, & 808.26 & -235.8, & 801.83 \\
0.0, & 791.81 & 5.8, & 791.08 \\
24.6, & 788.04 & 28.1, & 788.34 \\
38.1, & 790.29 & 44.5, & 792.04 \\
123.7, & 796.30 & 150.0, & 797.38 \\
229.8, & 794.14 & 384.5, & 793.38 \\
0.075 & 0.055 & 0.075
\end{array}
$$$$
-9
$$$$
-99.0,797.94
$$$$
10.0,788.57
$$$$
33.7,787.99
$$$$
69.7,794.74
$$$$
610.6,790.39
$$

0.0044

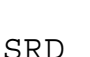

$$
\begin{array}{cc}
0 & 796.10 \\
0.0, & 796.18
\end{array}
$$$$
\text { LSEL }
$$

XSSKEW$$
0.0
$$

$0.6,794.80$

$12.5,788.35$

$21.9,788.45$

$44.5,795.15$

$$
\begin{array}{rr}
4.5, & 793.60 \\
26.8, & 788.28 \\
44.5, & 796.02
\end{array}
$$

$11.6,788.67$

$31.7,788.32$

$0.0,796.18$

$\begin{array}{rr}-29.4, & 792.28 \\ 13.7, & 788.20 \\ 37.2, & 788.69 \\ 88.8, & 794.78 \\ 727.0, & 795.08\end{array}$
BRTYPE BRWDTH EMBSS EMBELV

$$
\begin{array}{llll}
3 & 25.8 & 1.5 & 799.7
\end{array}
$$

0.055

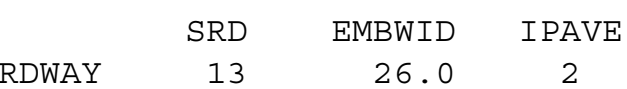

$$
-459.1,813.22-357
$$

$-2.1,799.30$

$-357.3,807.28$

$-1.4,799.72$

$-237.5,802.84$

$0.0,799.75$

$-114.7,800.16$

$47.4,799.03$

$63.6,802.29$

$540.7,794.11 \quad 735.2,795.72$

$\begin{array}{rr}72 & \\ -467.3, & 811.53 \\ -76.4, & 794.65 \\ 15.8, & 789.36 \\ 33.9, & 789.33\end{array}$

$$
\begin{array}{rr}
-401.1, & 806.96 \\
-10.3, & 793.76 \\
20.6, & 788.71
\end{array}
$$

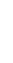
$-322.5,803.49$
$0.0,792.01$
$25.5,788.55$
$39.1,793.76$
$-125.1,798.74$
$7.2,789.73$
$30.4,788.71$
$63.6,802.29$

0.075 $-10.3$

796.181796 .18

796.18 * * 2330

798.341798 .34

$798.34 * * 2330$

796.181796 .18

796.18 * * 2824

799.96 * * 136

800.051800 .05 


\section{APPENDIX B: \\ WSPRO OUTPUT FILE}


WSPRO OUTPUT FILE

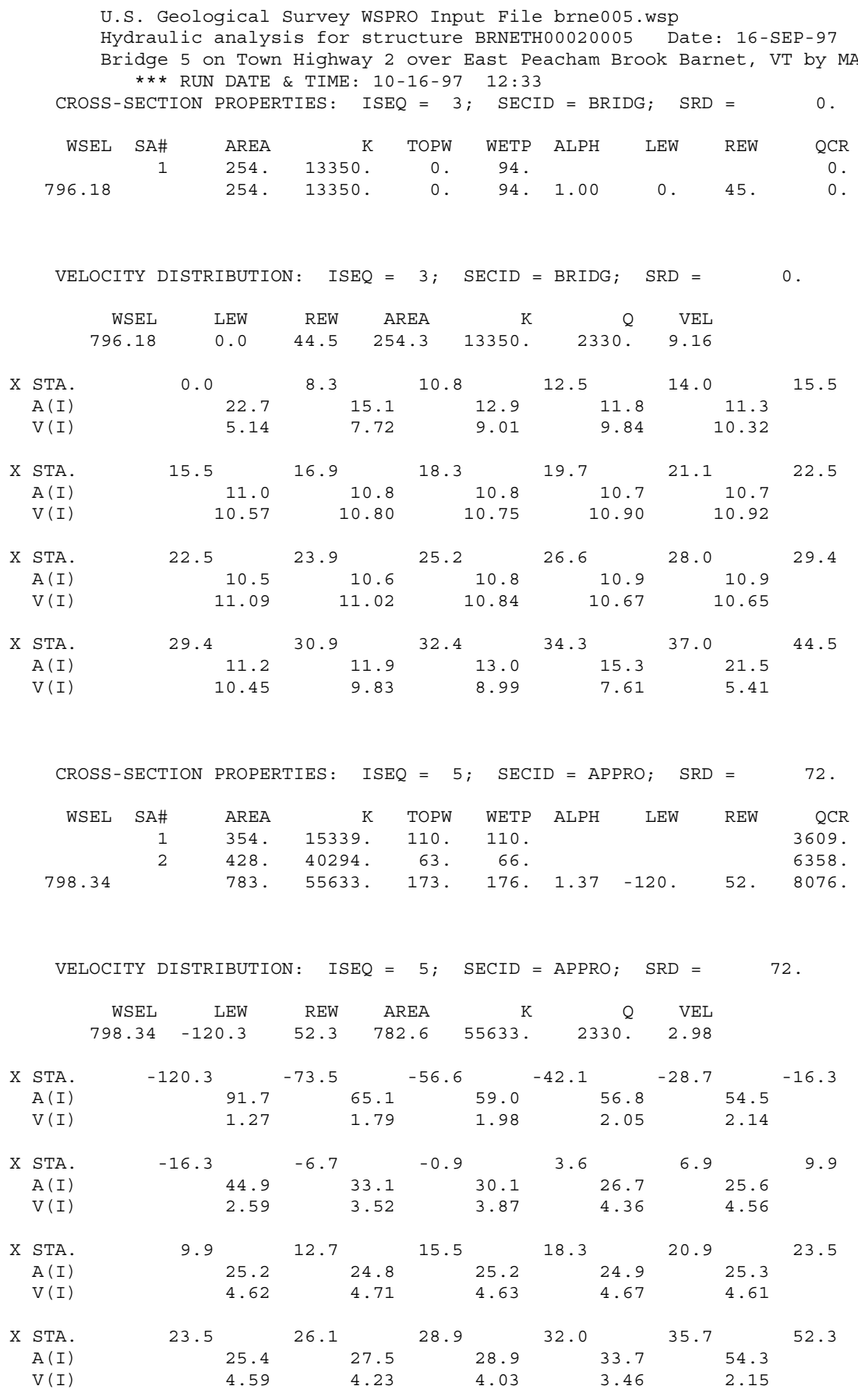


WSPRO OUTPUT FILE (continued)

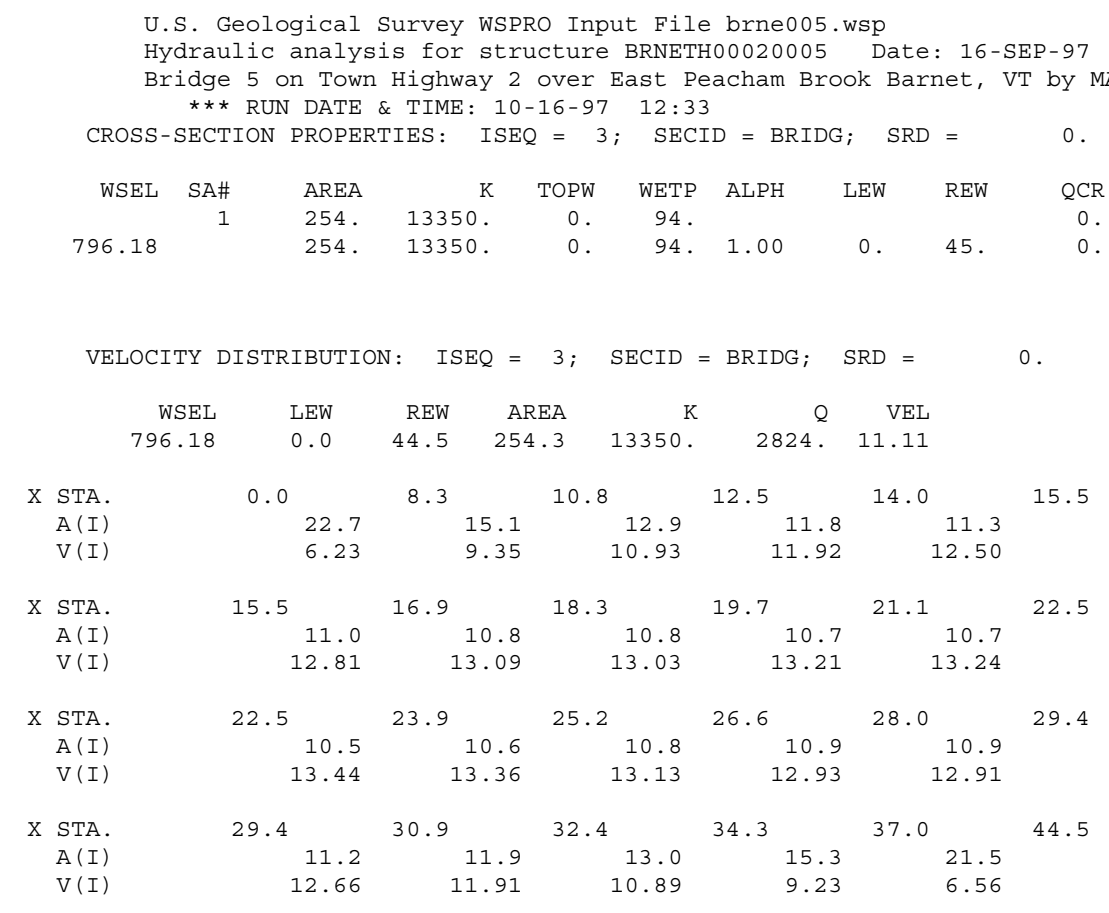

VELOCITY DISTRIBUTION: $\quad$ ISEQ $=4 ; \quad \operatorname{SECID}=$ RDWAY $; \quad$ SRD $=13$.

\begin{tabular}{|c|c|c|c|c|c|c|c|c|c|c|c|}
\hline & & ISEL & LEW & REW & & REA & $\mathrm{K}$ & $Q$ & VEL & & \\
\hline & 799 & .96 & -88.5 & 52.0 & & 4.8 & 466. & 136. & 3.03 & & \\
\hline & STA. & -88. & & -53.3 & & -42.7 & & 35.1 & -29.3 & & -24.3 \\
\hline & $A(I)$ & & 4.7 & & 3.3 & & 2.9 & 2.5 & & 2.3 & \\
\hline & $V(I)$ & & 1.44 & & 2.08 & & 2.35 & 2.73 & & 2.90 & \\
\hline & STA. & -24 . & & -20.0 & & -16.1 & & 12.7 & -9.5 & & -6.6 \\
\hline & $A(I)$ & & 2.2 & & 2.1 & & 1.9 & 1.9 & & 1.8 & \\
\hline & $V(I)$ & & 3.07 & & 3.26 & & 3.51 & 3.60 & & 3.81 & \\
\hline & STA. & -6 . & .6 & -3.8 & & 1.8 & & 12.0 & 20.4 & & 27.6 \\
\hline & $A(I)$ & & 1.8 & & 2.1 & & 2.3 & 2.2 & & 2.0 & \\
\hline & $\mathrm{V}(\mathrm{I})$ & & 3.88 & & 3.17 & & 2.90 & 3.11 & & 3.32 & \\
\hline & STA. & 27. & .6 & 33.9 & & 39.7 & & 44.9 & 48.0 & & 52.0 \\
\hline & $A(I)$ & & 1.9 & & 1.9 & & 1.8 & 1.5 & & 1.6 & \\
\hline & $V(I)$ & & 3.52 & & 3.63 & & 3.81 & 4.55 & & 4.21 & \\
\hline & CROSS - & SECTION & N PROPER' & TIES : & ISEQ & $2=5 ;$ & SECID & $D=A P P R O$ & SRD & $=$ & 72. \\
\hline & WSEL & SA\# & AREA & & $\mathrm{K}$ & TOPW & WETP & ALPH & LEW & REW & QCR \\
\hline & & 1 & 585. & 26579 & & 169. & 169. & & & & 6178. \\
\hline & & 2 & 539. & 56283 & & 67. & 71. & & & & 8654 . \\
\hline & 800.05 & & 1125. & 82863 & & 237. & 241. & 1.48 & 80. & 57. & 11419. \\
\hline
\end{tabular}

VELOCITY DISTRIBUTION $: \quad$ ISEQ $=5 ; \quad$ SECID $=$ APPRO $; \quad$ SRD $=72$.

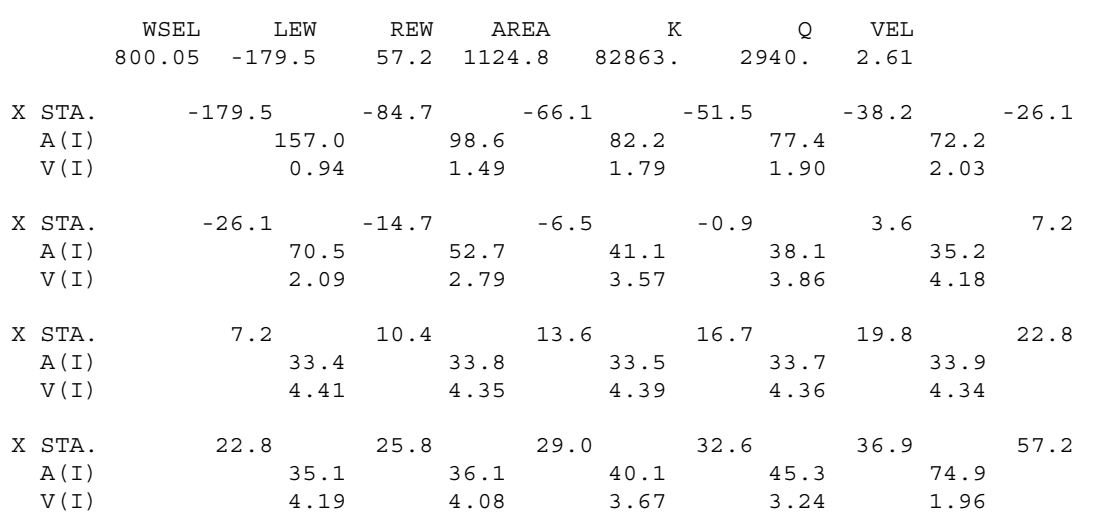


WSPRO OUTPUT FILE (continued)

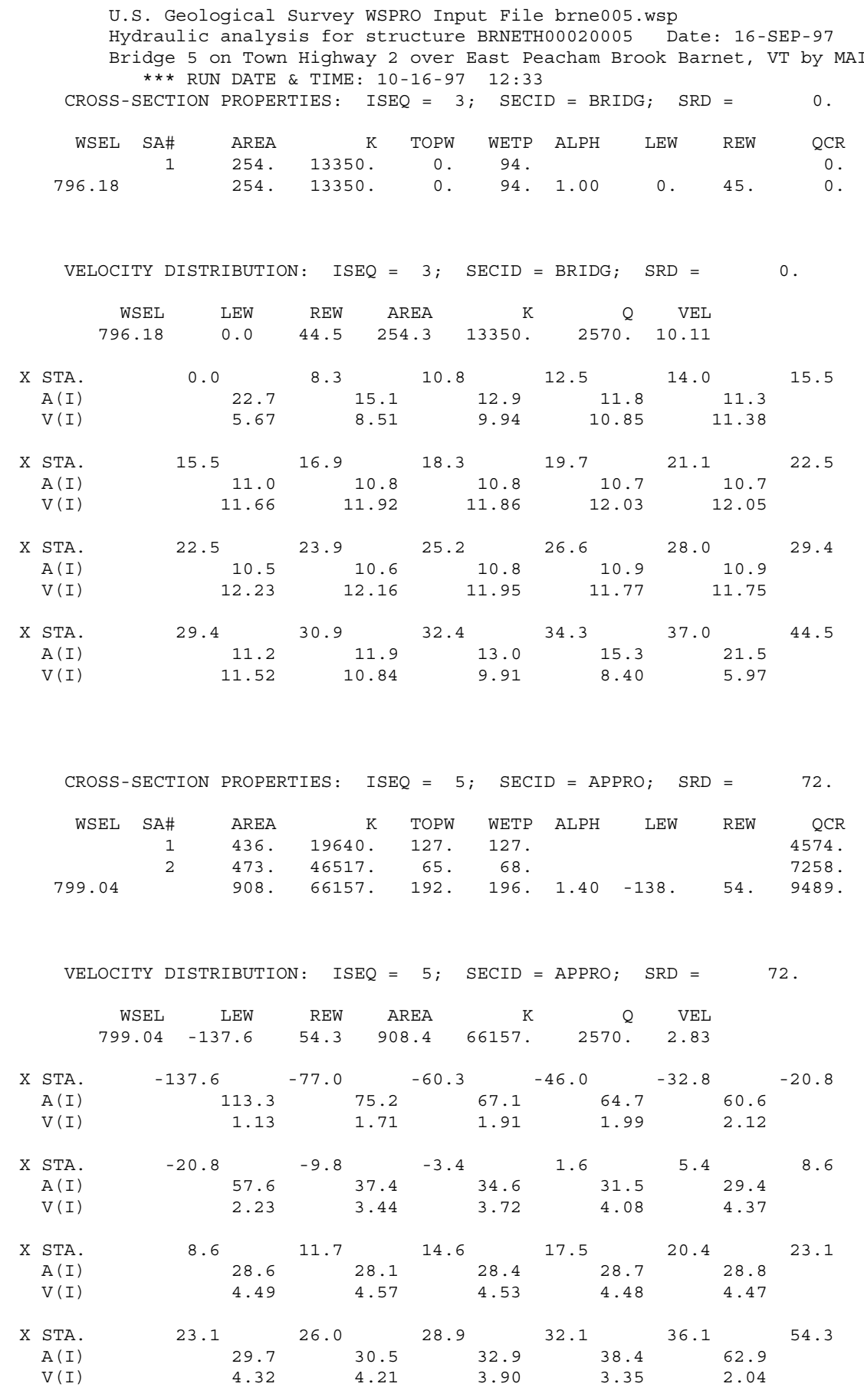


WSPRO OUTPUT FILE (continued)

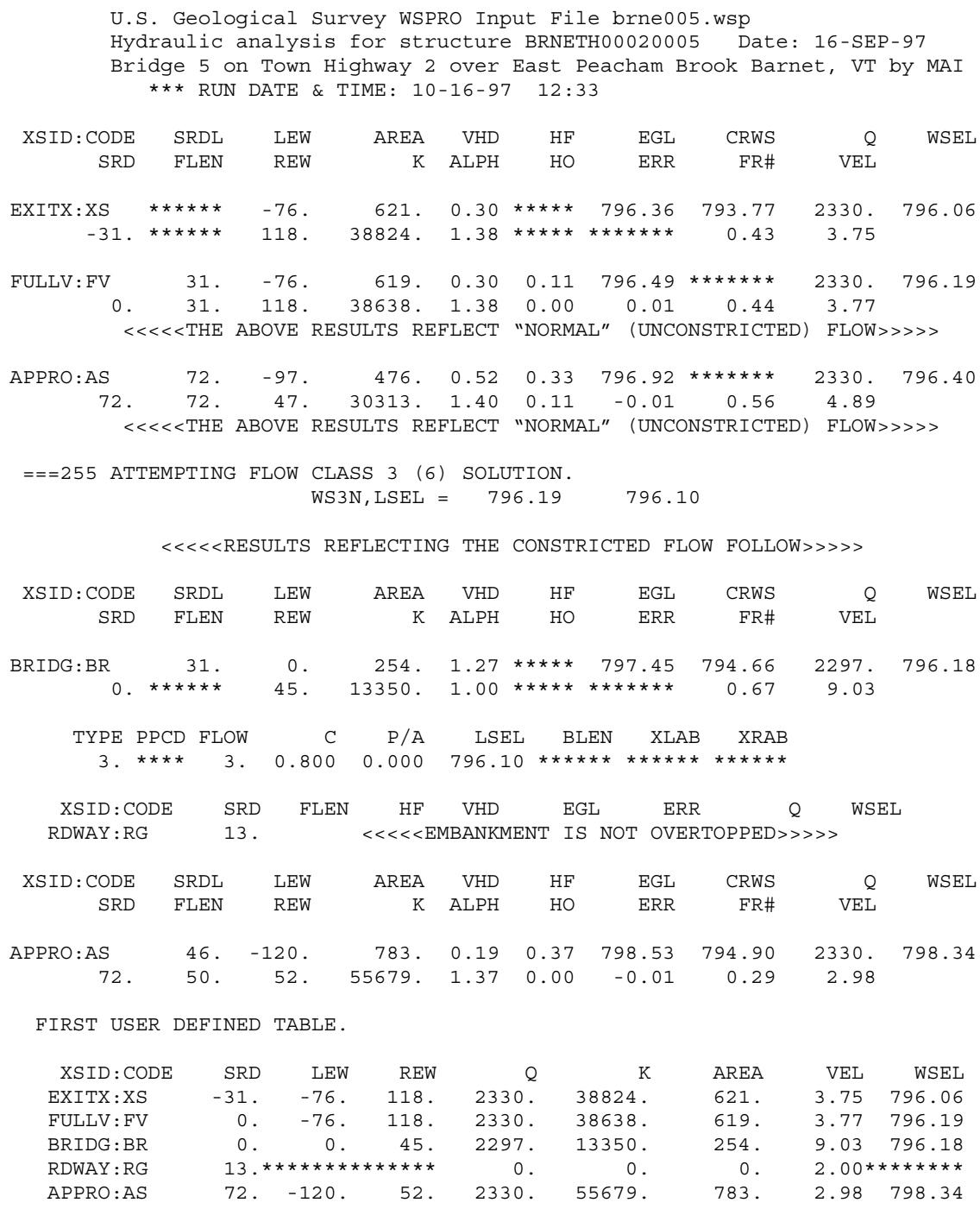

SECOND USER DEFINED TABLE.

\begin{tabular}{|c|c|c|c|c|c|c|c|c|c|}
\hline XSID : CODE & CRWS & FR\# & YMIN & YMAX & $\mathrm{HF}$ & $\mathrm{HO}$ & VHD & EGL & WSEL \\
\hline EXITX:XS & 793.77 & 0.43 & 787.99 & 808.26 * & $* * * * * *$ & 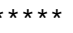 & 0.30 & 796.36 & 796.06 \\
\hline FULLV : FV & $\star * \star * \star * * *$ & 0.44 & 788.13 & 808.40 & 0.11 & 0.00 & 0.30 & 796.49 & 796.19 \\
\hline BRIDG : BR & 794.66 & 0.67 & 788.28 & 796.18 * & $* * * * * * *$ & 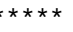 & 1.27 & 797.45 & 796.18 \\
\hline RDWAY : RG & $\star \star \star \star \star * \star * \star * \star *$ & $\star \star \star \star \star *$ & 799.03 & 813.22 * & 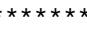 & 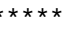 & 0.14 & 799.15 * & 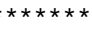 \\
\hline APPRO: AS & 794.90 & 0.29 & 788.55 & 811.53 & 0.37 & 0.00 & 0.19 & 798.53 & 798.34 \\
\hline
\end{tabular}


WSPRO OUTPUT FILE (continued)

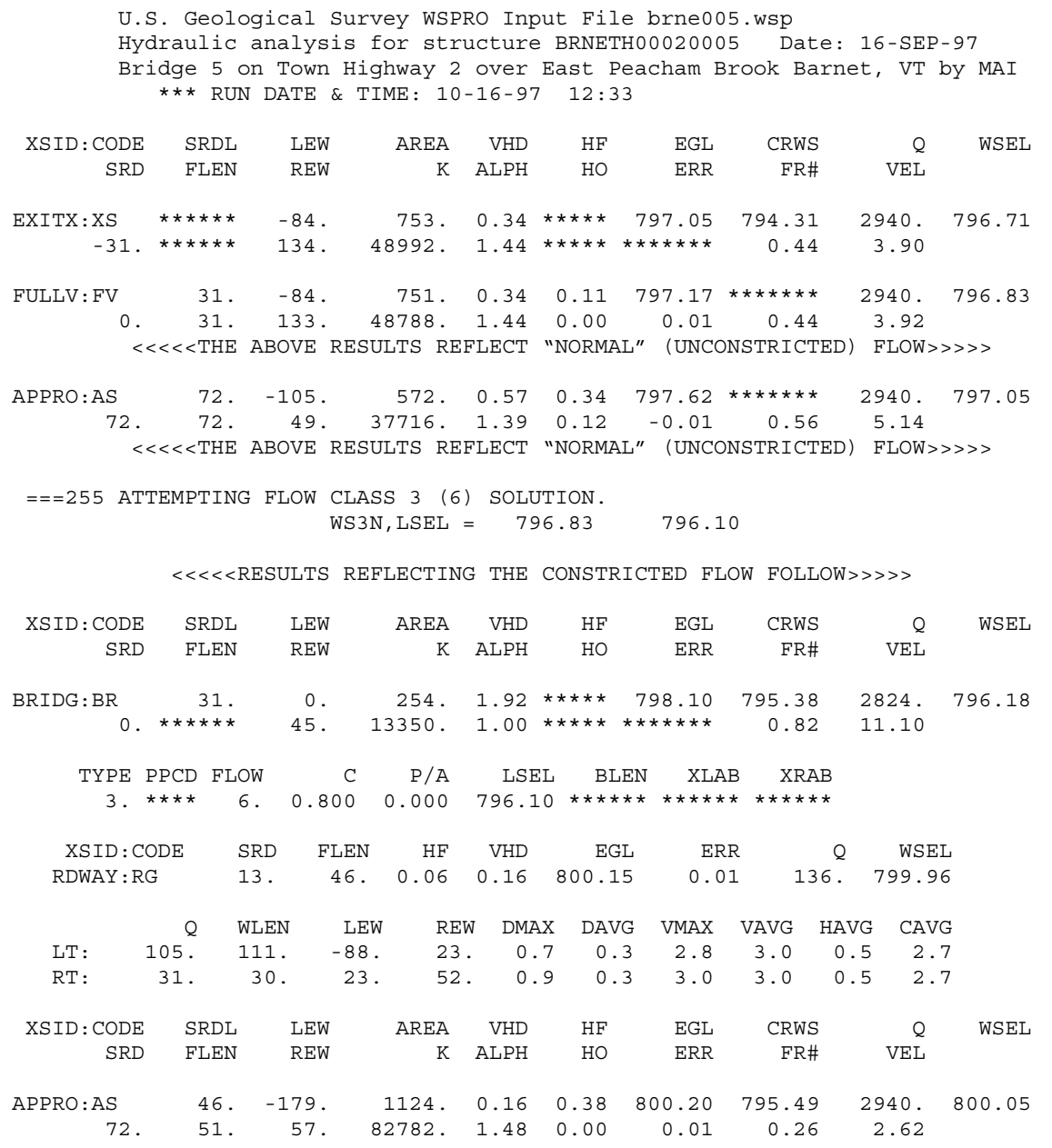

FIRST USER DEFINED TABLE.

$\begin{array}{lrrrrrrrr}\text { XSID : CODE } & \text { SRD } & \text { LEW } & \text { REW } & Q & \text { K } & \text { AREA } & \text { VEL } & \text { WSEL } \\ \text { EXITX : XS } & -31 . & -84 . & 134 . & 2940 . & 48992 . & 753 . & 3.90 & 796.71 \\ \text { FULLV : FV } & 0 . & -84 . & 133 . & 2940 . & 48788 . & 751 . & 3.92 & 796.83 \\ \text { BRIDG : BR } & 0 . & 0 . & 45 . & 2824 . & 13350 . & 254 . & 11.10 & 796.18 \\ \text { RDWAY : RG } & 13 . * * * * * * * & 105 . & 136 . * * * * * * * * * * * * * * * * & 2.00 & 799.96 \\ \text { APPRO : AS } & 72 . & -179 . & 57 . & 2940 . & 82782 . & 1124 . & 2.62 & 800.05\end{array}$

SECOND USER DEFINED TABLE.

\begin{tabular}{|c|c|c|c|c|c|c|c|c|c|}
\hline 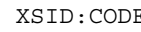 & CRWS & FR\# & N & YMAX & $\mathrm{HF}$ & $\mathrm{HO}$ & VHD & EGL & \\
\hline XITX:XS & 794.31 & .44 & 37.99 & 8.26 * & 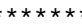 & & 0.34 & 97.05 & \\
\hline UI & 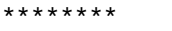 & & & 08.40 & 0.11 & 0.00 & 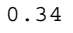 & 17 & \\
\hline$B R I$ & 5.38 & 0.82 & 8 & 96.18 * & $\star \star * *$ & $\star \star \star \star *$ & 2 & 10 & \\
\hline रG & $\star \star \star \star \star \star \star \star ~$ & 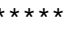 & 03 & 22 & 0.06 * & 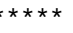 & 0.16 & 15 & \\
\hline PRO : AS & 795.49 & 0.26 & 788.55 & 811.53 & 0.38 & 0.00 & 0.16 & 800.20 & 0 \\
\hline
\end{tabular}


WSPRO OUTPUT FILE (continued)

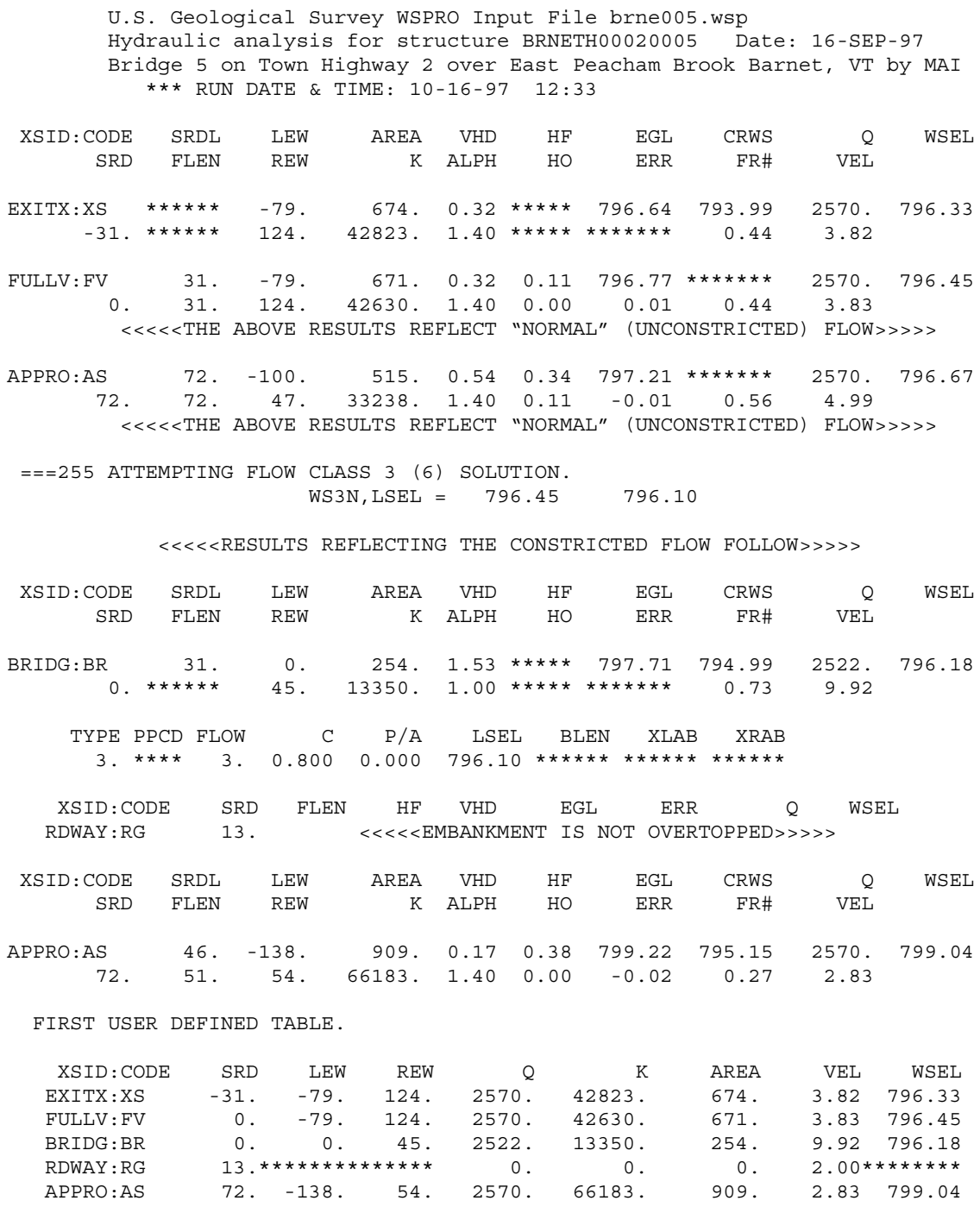

SECOND USER DEFINED TABLE.

$\begin{array}{lcrrrrrrrr}\text { XSID : CODE } & \text { CRWS } & \text { FR\# } & \text { YMIN } & \text { YMAX } & \text { HF } & \text { HO } & \text { VHD } & \text { EGL } & \text { WSEL } \\ \text { EXITX:XS } & 793.99 & 0.44 & 787.99 & 808.26 * * * * * * * * * * * & 0.32 & 796.64 & 796.33 \\ \text { FULLV:FV } & * * * * * * * & 0.44 & 788.13 & 808.40 & 0.11 & 0.00 & 0.32 & 796.77 & 796.45 \\ \text { BRIDG:BR } & 794.99 & 0.73 & 788.28 & 796.18 * * * * * * * * * * & 1.53 & 797.71 & 796.18 \\ \text { RDWAY: RG } & * * * * * * * * * * * * * * * & 799.03 & 813.22 * * * * * * * * * * * & 0.17 & 799.15 * * * * * * * \\ \text { APPRO:AS } & 795.15 & 0.27 & 788.55 & 811.53 & 0.38 & 0.00 & 0.17 & 799.22 & 799.04\end{array}$




\section{APPENDIX C:}

\section{BED-MATERIAL PARTICLE-SIZE DISTRIBUTION}




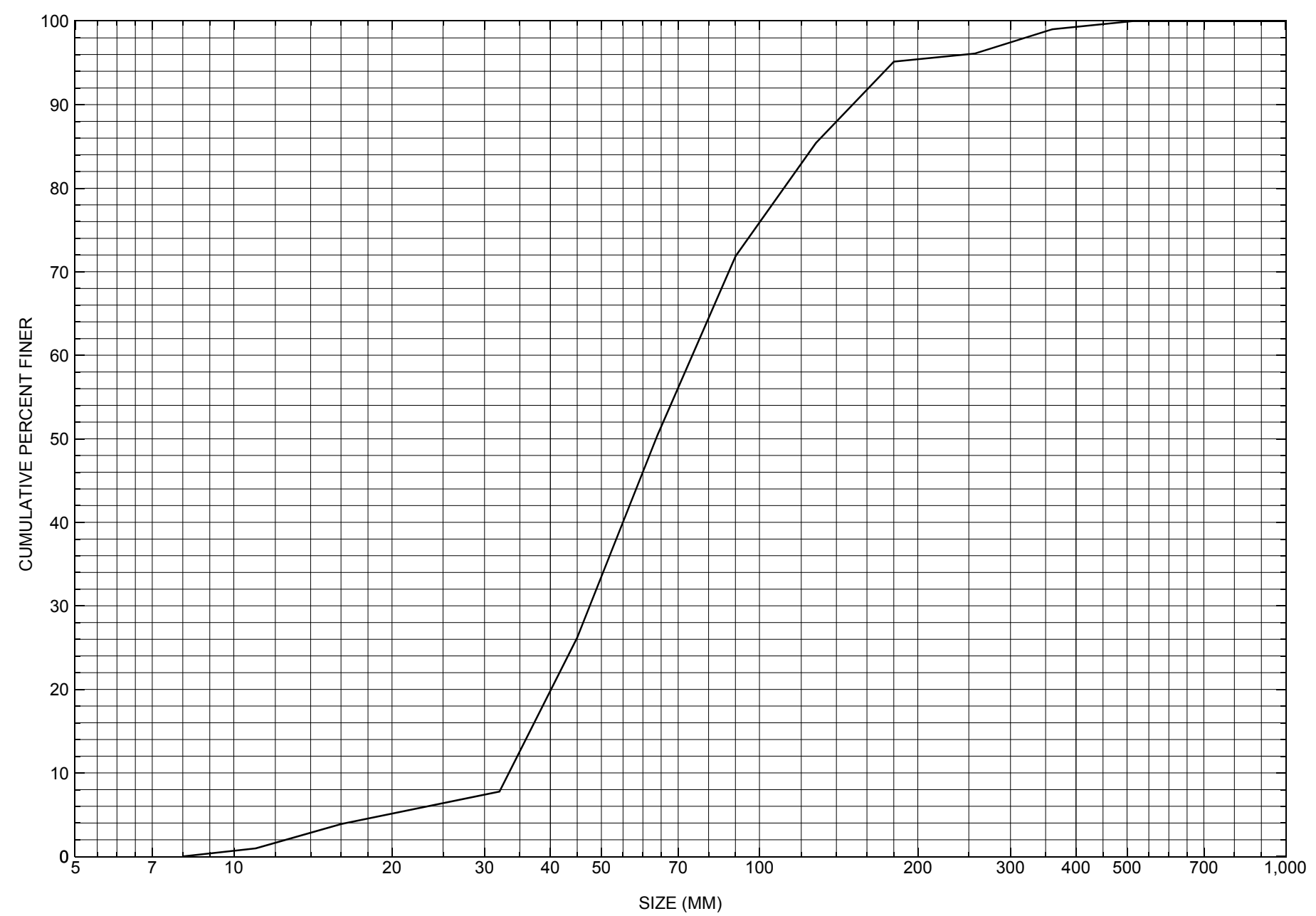

Appendix C. Bed material particle-size distribution for a pebble count in the channel approach of structure BRNETH00020005, in Barnet, Vermont. 


\section{APPENDIX D: \\ HISTORICAL DATA FORM}




\section{Structure Number BRNETH00020005}

\section{General Location Descriptive}

Data collected by (First Initial, Full last name) $\underline{\mathbf{E}}$. Boehmler

Date $(M M / D D / Y Y) \_\mathbf{0 3} / \underline{16} / \underline{95}$

Highway District Number (I - 2; nn) $\mathbf{0 7}$

Town (FIPS place code; I - 4; nnnnn) $\mathbf{0 2 8 7 5}$

Waterway (I - 6) East Peacham Brook

Route Number TH002

Topographic Map Barnet

Latitude (I - 16; nnnn.n) 44191
County (FIPS county code; I - 3; nnn)

Mile marker (I - 11; nnn.nnn) $\mathbf{0 0 0 0 0 0}$

Road Name (I - 7): -

Vicinity (I - 9) $\mathbf{0 . 1 5}$ miles to junction with TH61

Hydrologic Unit Code: $\mathbf{0 1 0 8 0 1 0 3}$

Longitude (i - 17; nnnnn.n) 72069

\section{Select Federal Inventory Codes}

FHWA Structure Number (I - 8) $\mathbf{1 0 0 3 0 1 0 0 0 5 0 3 0 1}$

Maintenance responsibility $(I-21 ; n n) \quad \mathbf{0 3}$

Year built (I - 27; YYYY) 1949

Average daily traffic, ADT (I - 29; nnnnnn) 000400

Year of ADT (I - 30; YY) $\mathbf{9 2}$

Opening skew to Roadway $(I-34 ; n n) \quad \mathbf{0 0}$

Operational status $(I-41 ; X) \quad \mathbf{A}$

Structure type (I- 43; nnn) $\mathbf{3 0 2}$

Approach span structure type $(I-44 ; n n n) \quad \mathbf{0 0 0}$

Number of spans (I - 45; nnn) $\underline{\mathbf{0 0 1}}$

Number of approach spans (I - 46; nnnn) $\mathbf{0 0 0 0}$

Comments:

The structural inspection report of 9/6/94 indicates the structure is a steel stringer type bridge with a concrete deck. The abutment walls and wingwalls are concrete. Both abutment walls are reported to have only a few fine cracks. The wingwalls are noted as small concrete walls that extend parallel to the abutment walls. The abutments, reportedly are protected with quarried granite blocks which are placed sloping down from the abutment walls forming spill-through ABUTMENTs through the bridge. The streambed is noted as primarily composed of gravel and cobbles. A gravel point bar is reported upstream on the left bank. Some log debris is noted just downstream of the bridge. The report indicates the footings are not in view at the surface and there has been no undermining or settling. 


\section{Bridge Hydrologic Data}

Is there hydrologic data available? $\underline{\mathbf{N}}$ if No, type ctrl- $n$ VTAOT Drainage area $\left(\mathrm{mi}^{2}\right)$ : -

Terrain character:

Stream character \& type: -

Streambed material: Gravel and cobbles

Discharge Data (cfs): $\quad Q_{2.33}$

$$
\mathrm{Q}_{50}
$$

Record flood date (MM / DD / YY): -

Estimated Discharge (cfs): I

$\mathrm{Q}_{10} \frac{-}{\mathrm{Q}_{100}-}$

$\mathrm{Q}_{25}$

Water surface elevation $(f t):-$

Ice conditions (Heavy, Moderate, Light) : -

Velocity at $\mathrm{Q}$ $(\mathrm{ft} / \mathrm{s}):$

The stage increases to maximum highwater elevation (Rapidly, Not rapidly):

The stream response is (Flashy, Not flashy):

Describe any significant site conditions upstream or downstream that may influence the stream's stage: -

Watershed storage area (in percent): - _ \%

The watershed storage area is: - _ (1-mainly at the headwaters; 2- uniformly distributed; 3-immediatly upstream oi the site)

Water Surface Elevation Estimates for Existing Structure:

\begin{tabular}{|l|l|l|l|l|l|}
\hline Peak discharge frequency & $Q_{2.33}$ & $Q_{10}$ & $Q_{25}$ & $Q_{50}$ & $Q_{100}$ \\
Water surface elevation (ft)) & - & - & - & - & - \\
Velocity (ft/sec) & - & - & - & - & - \\
\hline
\end{tabular}

Long term stream bed changes: -

Is the roadway overtopped below the $\mathrm{Q}_{100}$ ? (Yes, No, Unknown): $\mathbf{U} \quad$ Frequency: -

Relief Elevation (ft):

Discharge over roadway at $Q_{100}\left(f^{3} / \mathrm{sec}\right)$ :

Are there other structures nearby? (Yes, No, Unknown): $\mathbf{U}$ Upstream distance (miles): Town: If No or Unknown, type ctrl-n os Highway No. : Structure No. : Year Built:

Clear span (ft): Clear Height $(f t)$ : Full Waterway $\left(f t^{2}\right)$ : 
Downstream distance (miles): Town: Year Built:

Highway No. : Structure No. : Structure Type:

Clear span (ft): Clear Height $(f t)$ : Full Waterway $\left(f^{2}\right)$ : -

Comments:

\section{USGS Watershed Data}

Watershed Hydrographic Data

Drainage area $(D A) \underline{15.93} \mathrm{mi}^{2}$ Lake/pond/swamp area 0.12 $\mathrm{mi}^{2}$

Watershed storage (ST) 0.8 $\%$

Bridge site elevation 794 $\mathrm{ft}$

Headwater elevation 2566 $\mathrm{ft}$

Main channel length 9.414 $\mathrm{mi}$ $10 \%$ channel length elevation $\mathbf{8 5 6}$ $\mathrm{ft} \quad 85 \%$ channel length elevation $\mathrm{ft}$

Main channel slope (S) 111.19 $\mathrm{ft} / \mathrm{mi}$

Watershed Precipitation Data

Average site precipitation in Average headwater precipitation in

Maximum 2yr-24hr precipitation event $(124,2)$ in

Average seasonal snowfall (Sn) $\mathrm{ft}$ 


\section{Bridge Plan Data}

Are plans available? $\underline{Y}$ If no, type ctrl-n pl Date issued for construction (MM/YYYY): $\underline{06}$ / 1950 Project Number SA 631949 Minimum channel bed elevation: 92.5

Low superstructure elevation: USLAB $\underline{\mathbf{1 0 0 . 6 7}}$ DSLAB $\underline{\mathbf{1 0 0 . 6 7}}$ USRAB $\underline{\mathbf{1 0 0 . 5}}$ DSRAB $\underline{\mathbf{1 0 0 . 5}}$ Benchmark location description:

BM\#1, [spike in trunk or root of a] 34 inch twin elm tree located about 35 feet left bankward on the roadway from the left abutment and about $15 \mathrm{ft}$ to $20 \mathrm{ft}$ from the centerline of the roadway downstream, near left end of the downstream guard rail, elevation $100.00 \mathrm{ft}$

Reference Point (MSL, Arbitrary, Other): Arbitrary Datum (NAD27, NAD83, Other): Arbitrary Foundation Type: 1

If 1: Footing Thickness $\mathbf{2 . 0} \quad$ Footing bottom elevation: $\mathbf{9 5 . 7 *}$

If 2: Pile Type: ___ (1-Wood; 2-Steel or metal; 3-Concrete) Approximate pile driven length: If 3: Footing bottom elevation: Is boring information available? $\mathbf{N}$ If no, type ctrl-n bi Number of borings taken: _Foundation Material Type: $\mathbf{3}$ (1-regolith, 2-bedrock, 3-unknown) Briefly describe material at foundation bottom elevation or around piles: $-$

Comments:

*The bottom of footing elevation shown is proposed for the right abutment. The left bottom of footing elevation is proposed at $95.67 \mathrm{ft}$. The low superstructure elevations are the minimum and not the average. The abutments are shown as flow through type abutments. Other reference marks: 1 ) The point on top of the upstream end of the right abutment concrete on the streamward edge where the slope of the concrete changes from horizontal to sloping downward, elevation 103.50, or 2) The same point but on the upstream end of the left abutment, elevation 103.67. 


\section{Cross-sectional Data}

Is cross-sectional data available? $\mathbf{N}$ If no, type ctrl-n xs

Source (FEMA, VTAOT, Other)? -

Comments:

\section{NO CROSS SECTION INFORMATION}

\begin{tabular}{|l|l|l|l|l|l|l|l|l|l|l|l|}
\hline Station & - & - & - & - & - & - & - & - & - & - & - \\
\hline Feature & - & - & - & - & - & - & - & - & - & - & - \\
\hline $\begin{array}{l}\text { Low cord } \\
\text { elevation }\end{array}$ & - & - & - & - & - & - & - & - & - & - & - \\
\hline $\begin{array}{l}\text { Bed } \\
\text { elevation }\end{array}$ & - & - & - & - & - & - & - & - & - & - & - \\
\hline $\begin{array}{l}\text { Low cord to } \\
\text { bed length }\end{array}$ & - & - & - & - & - & - & - & - & - & - & - \\
\hline Station & - & - & - & - & - & - & - & - & - & - & - \\
\hline Feature & - & - & - & - & - & - & - & - & - & - & - \\
\hline $\begin{array}{l}\text { Low cord } \\
\text { elevation }\end{array}$ & - & - & - & - & - & - & - & - & - & - & - \\
\hline $\begin{array}{l}\text { Bed } \\
\text { elevation }\end{array}$ & - & - & - & - & - & - & - & - & - & - & - \\
\hline $\begin{array}{l}\text { Low cord to } \\
\text { bed length }\end{array}$ & - & - & - & - & - & - & - & - & - & - & - \\
\hline
\end{tabular}

Source (FEMA, VTAOT, Other)?

Comments: NO CROSS SECTION INFORMATION

\begin{tabular}{|l|l|l|l|l|l|l|l|l|l|l|l|}
\hline Station & - & - & - & - & - & - & - & - & - & - & - \\
\hline Feature & - & - & - & - & - & - & - & - & - & - & - \\
\hline $\begin{array}{l}\text { Low cord } \\
\text { elevation }\end{array}$ & - & - & - & - & - & - & - & - & - & - & - \\
\hline $\begin{array}{l}\text { Bed } \\
\text { elevation }\end{array}$ & - & - & - & - & - & - & - & - & - & - & - \\
\hline $\begin{array}{l}\text { Low cord to } \\
\text { bed length }\end{array}$ & - & - & - & - & - & - & - & - & - & - & - \\
\hline Station & - & - & - & - & - & - & - & - & - & - & - \\
\hline Feature & - & - & - & - & - & - & - & - & - & - & - \\
\hline $\begin{array}{l}\text { Low cord } \\
\text { elevation }\end{array}$ & - & - & - & - & - & - & - & - & - & - & - \\
\hline $\begin{array}{l}\text { Bed } \\
\text { elevation }\end{array}$ & - & - & - & - & - & - & - & - & - & - & - \\
\hline $\begin{array}{l}\text { Low cord to } \\
\text { bed length }\end{array}$ & - & - & - & - & - & - & - & - & - & - & - \\
\hline
\end{tabular}




\section{APPENDIX E: \\ LEVEL I DATA FORM}


U. S. Geological Survey

Bridge Field Data Collection and Processing Form

Qa/Qc Check by: $\mathbf{C G}$ Date: $\mathbf{0 2 / 2 3 / 9 6}$

\section{Structure Number}

BRNETH00020005 Date: $02 / 27 / 96$

\section{A. General Location Descriptive}

1. Data collected by (First Initial, Full last name) $\underline{\mathbf{L}}$. Medalie

2. Highway District Number $\mathbf{0 7}$

Mile marker 0000000

County Caledonia (005)

Waterway (I - 6) East Peacham Brook

Town Barnet (02875)

Route Number TH 02

Road Name -

Hydrologic Unit Code: $\mathbf{0 1 0 8 0 1 0 3}$

3. Descriptive comments:

The site is located 0.15 miles to the junction with Town Highway 61.

\section{B. Bridge Deck Observations}
4. Surface cover... LBUS 6
RBUS 6
LBDS 6
RBDS 6
Overall 6

(2b us, ds,lb,rb: 1- Urban; 2- Suburban; 3- Row crops; 4- Pasture; 5- Shrub- and brushland; 6- Forest; 7- Wetland)
5. Ambient water surface... US $\underline{2}$
UB 2
DS $\underline{2}$
(1- pool; 2- riffle)

6. Bridge structure type 1 (1- single span; 2- multiple span; 3- single arch; 4- multiple arch; 5-cylindrical culvert; 6- box culvert; or 7- other)
7. Bridge length 49.0
(feet)
Span length $\underline{\mathbf{4 6 . 0}}$
(feet)
Bridge width 26.0 (feet)

\section{Road approach to bridge:}
8. LB 0
RB 0
( 0 even, 1- lower, 2- higher)
9. LB_2
RB $\underline{2}$
(1-Paved, 2- Not paved)

10. Embankment slope (run / rise in feet / foot)

$$
\text { US left }
$$

1.3:1

US right

1.7:1

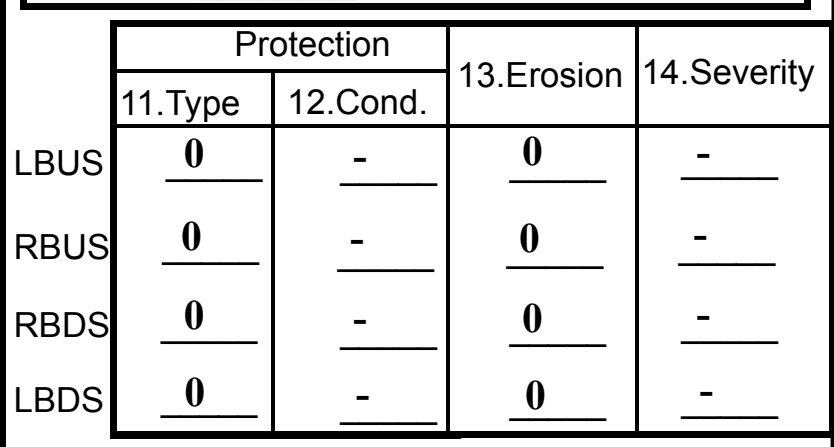

Bank protection types: 0- none; 1- $<12$ inches;

2- < 36 inches; 3- < 48 inches;

4- < 60 inches; 5- wall / artificial levee

Bank protection conditions: 1- good; 2- slumped;

3- eroded; 4- failed

Erosion: 0 - none; 1- channel erosion; 2 -

road wash; 3- both; 4- other

Erosion Severity: 0 - none; 1- slight; 2- moderate; 3- severe

\section{Channel approach to bridge (BF):}

15. Angle of approach: $\mathbf{0}$

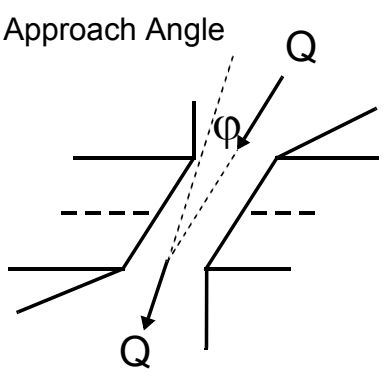

17. Channel impact zone 1 :

Where? RB (LB, RB)

Range? 70 feet US

Channel impact zone 2:

Where? $(L B, R B)$

Range? - $\quad$ feet -

(US, UB, DS) to feet Impact Severity: 0- none to very slight; 1- Slight; 2- Moderate; 3- Severe

16. Bridge skew: $\mathbf{0}$ Bridge Skew Angle

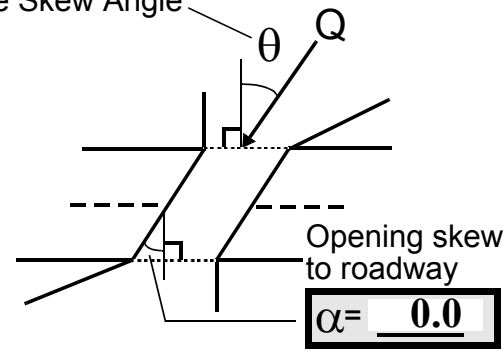

\section{Exist? $\mathbf{Y}(Y$ or $N)$}

Severity 1

(US, UB, DS) to $\underline{\mathbf{1 0 0}}$ feet $\underline{\mathbf{U S}}$

Exist? $\mathbf{N}(Y$ or $N)$

Severity - 
18. Bridge Type: $\mathbf{3}$

1a- Vertical abutments with wingwalls

1 b- Vertical abutments without wingwalls

2- Vertical abutments and wingwalls, sloping embankment Wingwalls parallel to abut. face

3- Spill through abutments

4- Sloping embankment, vertical wingwalls and abutments

Wingwall angle less than $90^{\circ}$.

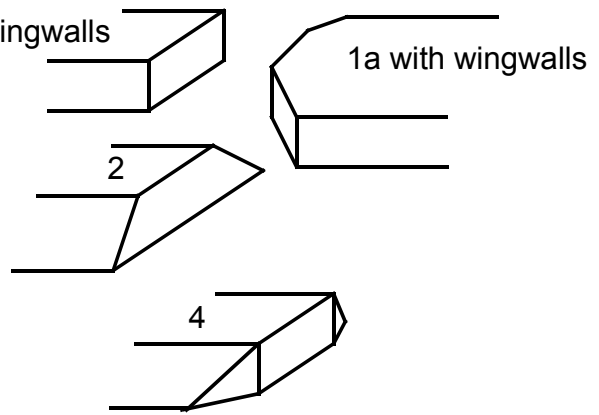

19. Bridge Deck Comments (surface cover variations, measured bridge and span lengths, bridge type variations, approach overflow width, etc.)

7. The bridge dimension values are from the VTAOT. The measured dimensions are bridge length is $48.5 \mathrm{ft}$, span length is $45.5 \mathrm{ft}$, and deck width is $25.6 \mathrm{ft}$.

8. The left bank road approach is even for about 50 feet and then slightly higher.

\section{Upstream Channel Assessment}

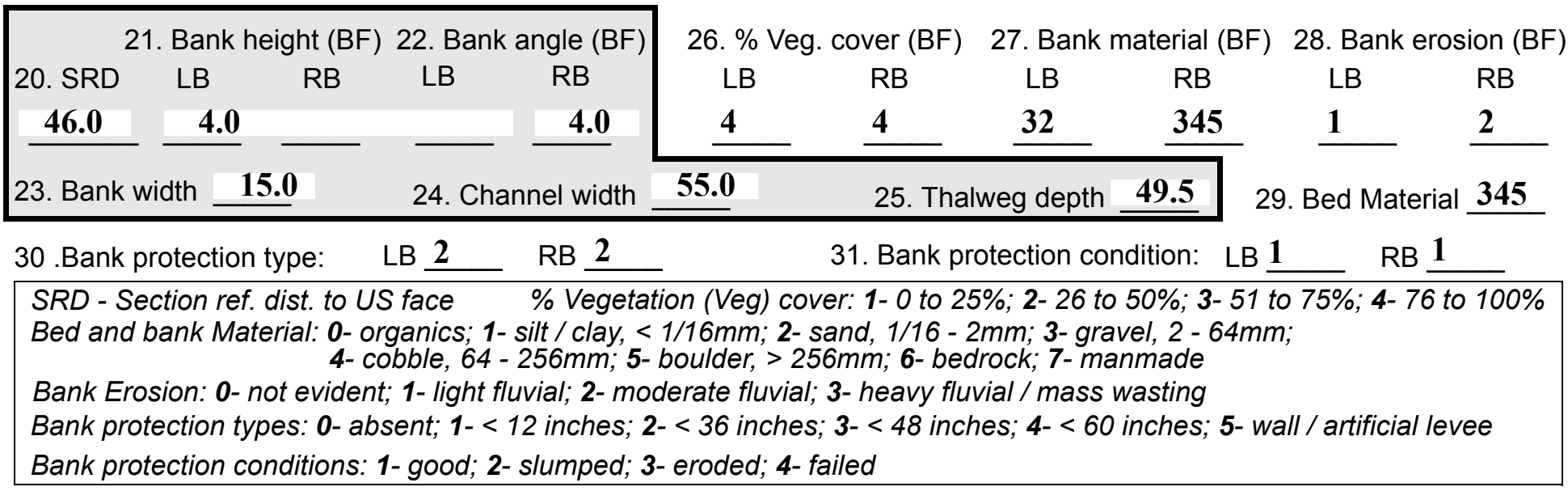

32. Comments (bank material variation, minor inflows, protection extent, etc.):

The bank protection is comprised of the stone slabs that form the spill through abutments. The right bank protection extends $18 \mathrm{ft}$ upstream. The left bank protection extends $21 \mathrm{ft}$ upstream.

There are more cut banks, impact zones, downed trees, and side bars beyond $100 \mathrm{ft}$ upstream of the bridge. 
33.Point/Side bar present? Y

$(Y$ or $N$. if $N$ type ctrl-n pb)34. Mid-bar distance: $\mathbf{5 8}$

35. Mid-bar width: 15

36. Point bar extent: 6 feet US

(US, UB) to 100 feet $\underline{\text { US }}$

(US, UB, DS) positioned $\mathbf{0}$ $\%$ LB to 35 $\%$ RB

37. Material: $\mathbf{3 4 2}$

38. Point or side bar comments (Circle Point or Side); Note additional bars, material variation, status, etc.):

39. Is a cut-bank present? $\mathbf{Y}$ (Y or if $N$ type ctrl-n cb) 40. Where? $\underline{\mathbf{R B}}$ (LB or RB)

41. Mid-bank distance: $\mathbf{8 0}$

42. Cut bank extent: 31

\section{0.} feet $\underline{\text { US }}$ (US, UB, DS)

43. Bank damage: 1 (1- eroded and/or creep; 2- slip failure; 3- block failure)

44. Cut bank comments (eg. additional cut banks, protection condition, etc.):

There are some trees on the cut bank that are tilted at about a 30 degree angle over the stream.

\section{Is channel scour present? $\mathbf{N}$ ( $Y$ or if $N$ type ctrl-n cs)}

47. Scour dimensions: Length Width -

Depth :-

46. Mid-scour distance: -

48. Scour comments (eg. additional scour areas, local scouring process, etc.):

\section{NO CHANNEL SCOUR}

There is some minor local scour around boulders 24-33 feet upstream from the bridge.

49. Are there major confluences? $\mathbf{N}$

51. Confluence 1: Distance Confluence 2: Distance -

54. Confluence comments (eg. confluence name):

NO MAJOR CONFLUENCES
( $Y$ or if $N$ type ctrl-n mc)

52. Enters on -

Enters on ( $L B$ or $R B$ ) ( $L B$ or $R B$ )
50. How many? -

53. Type(1-perennial; 2- ephemeral)

Type (1-perennial; 2- ephemeral)

NO MAJOR CONFLUENCES

\section{Under Bridge Channel Assessment}

55. Channel restraint (BF)? LB 2

\begin{tabular}{|c|c|}
\hline 56. Height (BF) & 57 Angle (BF) \\
\hline $\mathrm{RB}$ & LB \\
\hline
\end{tabular}

58. Bank width (BF) -

1.0

Bed and bank Material:

59. Channel width -

61. Material (BF)

LB RB

$2 \quad 7$

62. Erosion (BF)

LB RB

7 $\%$ RB

Bed and bank Material: 0- organics; 1- silt / clay, < 1/16mm; 2- sand, 1/16 - 2mm; 3- gravel, 2 - 64mm; 4- cobble, 64 - 256mm; 5- boulder, > 256mm; 6- bedrock; 7- manmade

Bank Erosion: 0- not evident; 1- light fluvial; 2- moderate fluvial; 3- heavy fluvial / mass wasting

64. Comments (bank material variation, minor inflows, protection extent, etc.):

34 
65. Debris and Ice Is there debris accumulation?

(Yor $N)$ 66. Where? $\underline{Y}$ (1- Upstream; 2- At bridge; 3- Both)

67. Debris Potential 1 ( 1- Low; 2- Moderate; 3- High) 68. Capture Efficiency 2 (1-Low; 2- Moderate; 3- High) 69. Is there evidence of ice build-up? 2 Ice Blockage Potential $\mathbf{N}$ (1-Low; 2- Moderate; 3- High) 70. Debris and Ice Comments:

1

Some trees have fallen into the channel beginning around $65 \mathrm{ft}$ from the bridge and further upstream. 68 . Capture efficiency is moderate because the bridge opening is less than $60 \%$ of the bank width.

\begin{tabular}{|l|c|c|c|c|c|c|c|c|}
\hline Abutments & $\begin{array}{c}\text { 71. Attack } \\
\angle \text { (BF) }\end{array}$ & $\begin{array}{c}\text { 72. Slope } \angle \\
\text { (Qmax) }\end{array}$ & $\begin{array}{c}\text { 73. Toe } \\
\text { loc. (BF) }\end{array}$ & $\begin{array}{c}\text { 74. Scour } \\
\text { Condition }\end{array}$ & $\begin{array}{c}75 . \text { Scour } \\
\text { depth }\end{array}$ & $\begin{array}{c}\text { 76. Exposure } \\
\text { depth }\end{array}$ & 77. Material & 78. Length \\
\hline LABUT & & $\mathbf{0}$ & $\mathbf{4 5}$ & $\mathbf{2}$ & $\mathbf{0}$ & - & - & $\mathbf{9 0 . 0}$ \\
\hline RABUT & $\mathbf{1}$ & $\mathbf{0}$ & $\mathbf{4 5}$ & & & $\mathbf{2}$ & $\mathbf{0}$ & $\mathbf{4 4 . 5}$ \\
\hline
\end{tabular}

Pushed: $L B$ or RB

Toe Location (Loc.): 0- even, 1- set back, 2- protrudes

Scour cond.: 0- not evident; 1- evident (comment); 2- footing exposed; 3-undermined footing; 4- piling exposed; 5- settled; 6- failed

Materials: 1- Concrete; 2- Stone masonry or drywall; 3- steel or metal; 4- wood

79. Abutment comments (eg. undermined penetration, unusual scour processes, debris, etc.):

$-$

1

72. The top concrete section is at an 80 degree 1-2 ft from the top to the bottom. There are blocks of stone at the base of the left and right vertical concrete abutments forming spill-through abutments.

80. Wingwalls: $\begin{array}{lllll} & & & & \\ \text { Exist? Material? } & \text { Scour } & \text { Scour } & \text { Exposure } & \text { Angle? Length? } \\ & \text { Condition? depth? depth? } & & \end{array}$ USLWW:

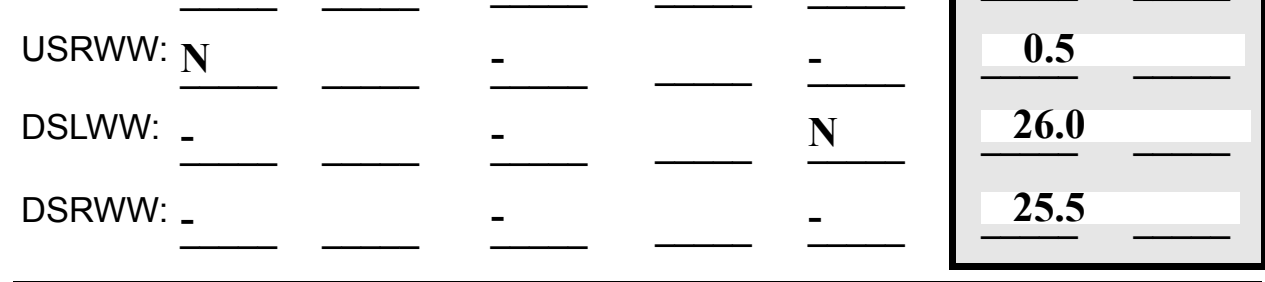

Wingwall materials: 1- Concrete; 2- Stone masonry or drywall; 3- steel or metal; 4- wood

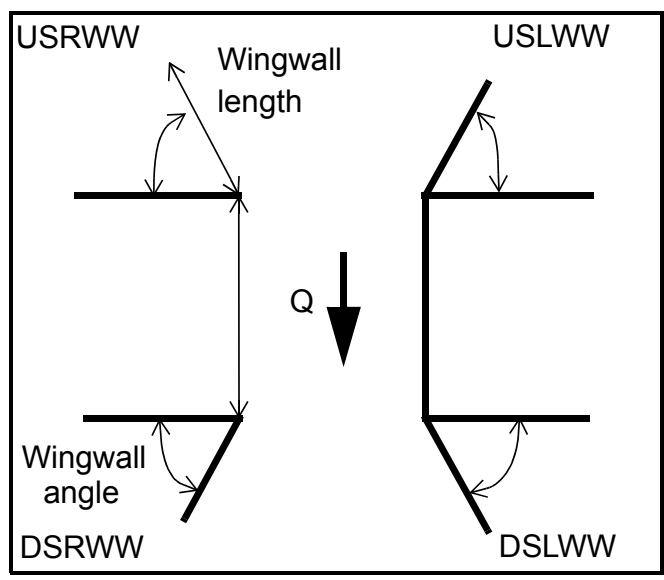

82. Bank / Bridge Protection:

\begin{tabular}{|l|l|l|l|l|l|l|l|c|}
\hline Location & USLWW & USRWW & LABUT & RABUT & LB & RB & DSLWW & DSRWW \\
\hline Type & - & - & N & - & - & - & $\mathbf{1}$ & $\mathbf{1}$ \\
\hline Condition & N & - & - & - & - & - & $\mathbf{1}$ & $\mathbf{1}$ \\
\hline Extent & - & - & - & - & - & $\mathbf{2}$ & $\mathbf{2}$ & - \\
\hline
\end{tabular}

Bank / Bridge protection types: 0- absent; 1- < 12 inches; 2- < 36 inches; 3- < 48 inches; 4- < 60 inches; 
83. Wingwall and protection comments (eg. undermined penetration, unusual scour processes, etc.):

-
-
-
-
-
-
-
-
-
-

\section{Piers:}

84. Are there piers? 82. (Y or if $N$ type ctrl-n pr)

\begin{tabular}{|l|l|l|l|l|l|l|l|}
\hline \multirow{2}{*}{$\begin{array}{l}85 . \\
\text { Pier no. }\end{array}$} & \multicolumn{3}{|c|}{ width (w) feet } & \multicolumn{3}{c|}{ elevation (e) feet } \\
\cline { 2 - 8 } & w1 & w2 & w3 & e@w1 & e@w2 & e@w3 \\
\hline Pier 1 & - & - & - & - & - & - \\
\hline Pier 2 & - & - & - & - & - & - \\
\hline Pier 3 & - & - & - & - & - & - \\
\hline Pier 4 & - & - & - & - & - & - \\
\hline
\end{tabular}

\begin{tabular}{|l|l|l|l|l|}
\hline Level 1 Pier Descr. & \multicolumn{1}{|c|}{1} & \multicolumn{1}{|c|}{2} & \multicolumn{1}{|c|}{3} & \multicolumn{1}{|c|}{4} \\
\hline 86. Location (BF) & All & placed & This & as \\
\hline 87. Type & pro- & stone & pro- & note \\
\hline 88. Material & tec- & bloc & tec- & d in \\
\hline 89. Shape & tion & ks & tion & upst \\
\hline 90. Inclined? & for & form & exte & ream \\
\hline 91. Attack $\angle$ (BF) & the & ing & nds & and \\
\hline 92. Pushed & abut & the & upst & dow \\
\hline 93. Length (feet) & - & - & - & - \\
\hline 94. \# of piles & ment & spill & ream & nstre \\
\hline 95. Cross-members & s & thro & and & am \\
\hline 96. Scour Condition & refer & ugh & dow & sec- \\
\hline 97. Scour depth & s to & slope & nstre & tions \\
\hline 98. Exposure depth & the & s. & am & . \\
\hline
\end{tabular}

LFP, LTB, LB, MCL, MCM, MCR, RB, RTB, RFP

1- Solid pier, 2-column, 3- bent

1-Wood; 2-concrete; 3- metal; 4- stone

1- Round; 2- Square; 3- Pointed

Y-yes; $N$ - no

$L B$ or $R B$

0- none; 1- laterals; 2- diagonals; 3- both

0- not evident; 1- evident (comment);

2- footing exposed; 3- piling exposed;

4- undermined footing; 5- settled; 6- failed 
99. Pier comments (eg. undermined penetration, protection and protection extent, unusual scour processes, etc.):

The stone blocks are $2.5 \mathrm{ft}$ wide.

$\mathbf{N}$

100.

\section{E. Downstream Channel Assessment}

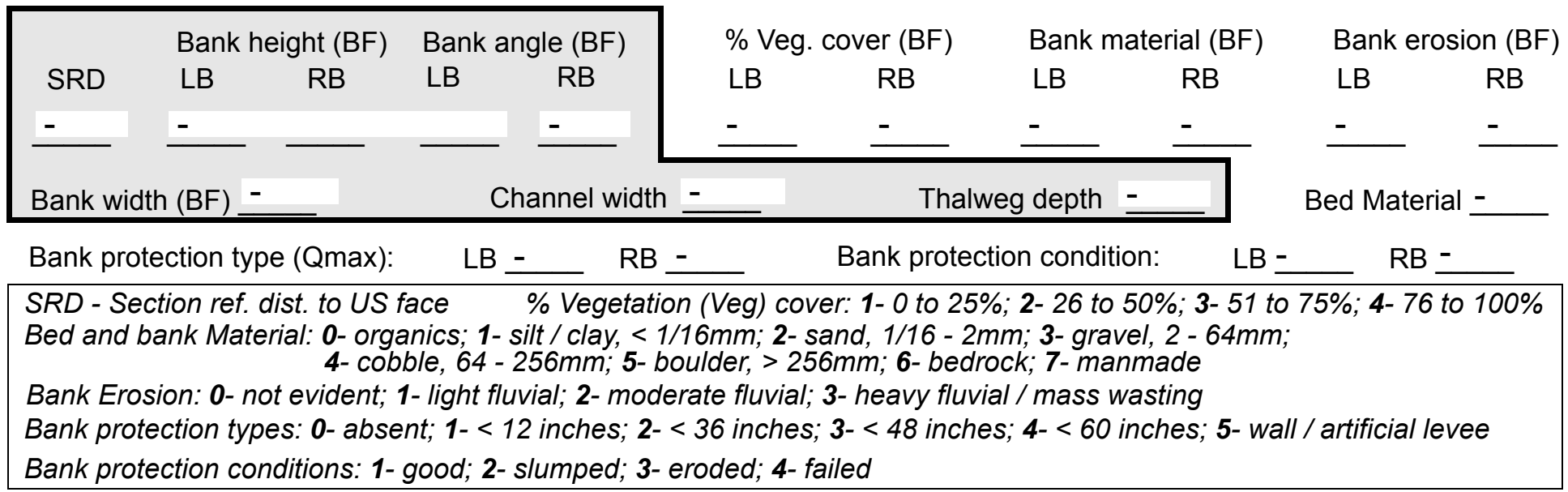

Comments (eg. bank material variation, minor inflows, protection extent, etc.):

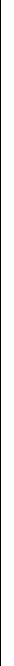

\section{Is a drop structure present? __ ( $Y$ or $N$, if $N$ type ctrl-n $d s) \quad$ 102. Distance: ___ feet}

103. Drop: __ feet 104. Structure material: ___ (1- steel sheet pile; 2- wood pile; 3- concrete; 4- other)

105. Drop structure comments (eg. downstream scour depth): 
106. Point/Side bar present? (Y or $N$. if $N$ type ctrl-n pb)Mid-bar distance:

Mid-bar width: -

Point bar extent: feet -

(US, UB, DS) to feet (US, UB, DS) positioned $\%$ LB to $\% \mathrm{RB}$ Material:

Point or side bar comments (Circle Point or Side); note additional bars, material variation, status, etc.):

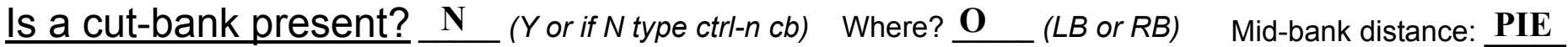
Cut bank extent: $\underline{\mathbf{R S}}$ feet ___ (US, UB, DS) to feet (US, UB, DS)

Bank damage: (1- eroded and/or creep; 2- slip failure; 3- block failure)

Cut bank comments (eg. additional cut banks, protection condition, etc.):

Is channel scour present? Scour dimensions: Length $\underline{4}$ Width 432 Depth: 453

Scour comments (eg. additional scour areas, local scouring process, etc.): 34

2

2

1

Are there major confluences? 1 ( 1 or if $N$ type ctrl-n $m c)$

Confluence 1: Distance left Enters on ban (LB or RB)

Enters on tec- $(L B$ or RB)

Confluence 2: Distance pro-

Confluence comments (eg. confluence name):

extends $18 \mathrm{ft}$ downstream.

The right bank protection extends $21 \mathrm{ft}$ downstream. Also, the right bank protection consists of a couple of

\section{F. Geomorphic Channel Assessment}

$\begin{array}{ll}\text { 107. Stage of reach evolution hor } & \text { 1- Constructed } \\ & \text { 2-Stable } \\ \text { 3- Aggraded } \\ \text { 4- Degraded } \\ \text { 5- Laterally unstable } \\ \text { 6- Vertically and laterally unstable }\end{array}$


108. Evolution comments (Channel evolution not considering bridge effects; See HEC-20, Figure 1 for geomorphic descriptors):

izontal slabs in the stream bed.

The reach is very straight to $150 \mathrm{ft}$ downstream. The channel makes a sharp bend to the right back towards Town Highway 2. There are several large trees in the channel at $150 \mathrm{ft}$ downstream. The streambed becomes sandy and the right bank becomes moderately eroded beyond $115 \mathrm{ft}$ downstream. There is a scour hole on the left bank and a narrow point bar on the right bank about $160 \mathrm{ft}$ downstream. 


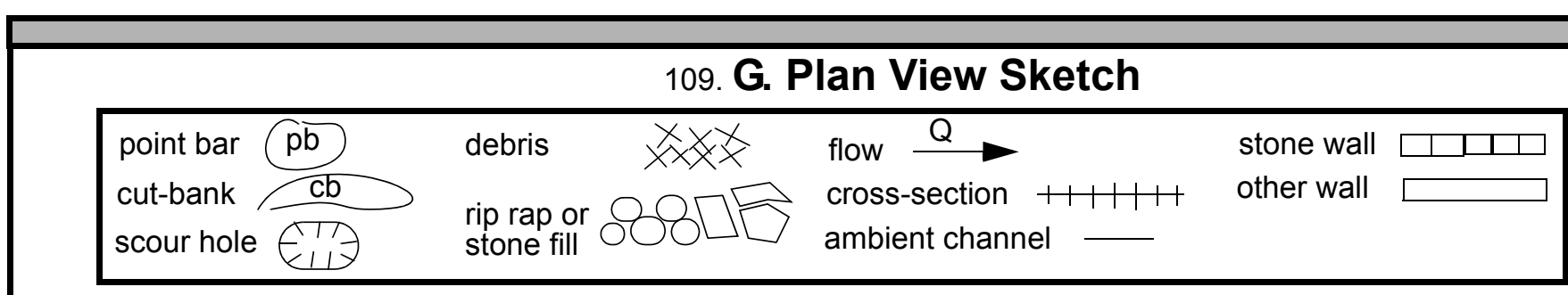


APPENDIX F:

SCOUR COMPUTATIONS 


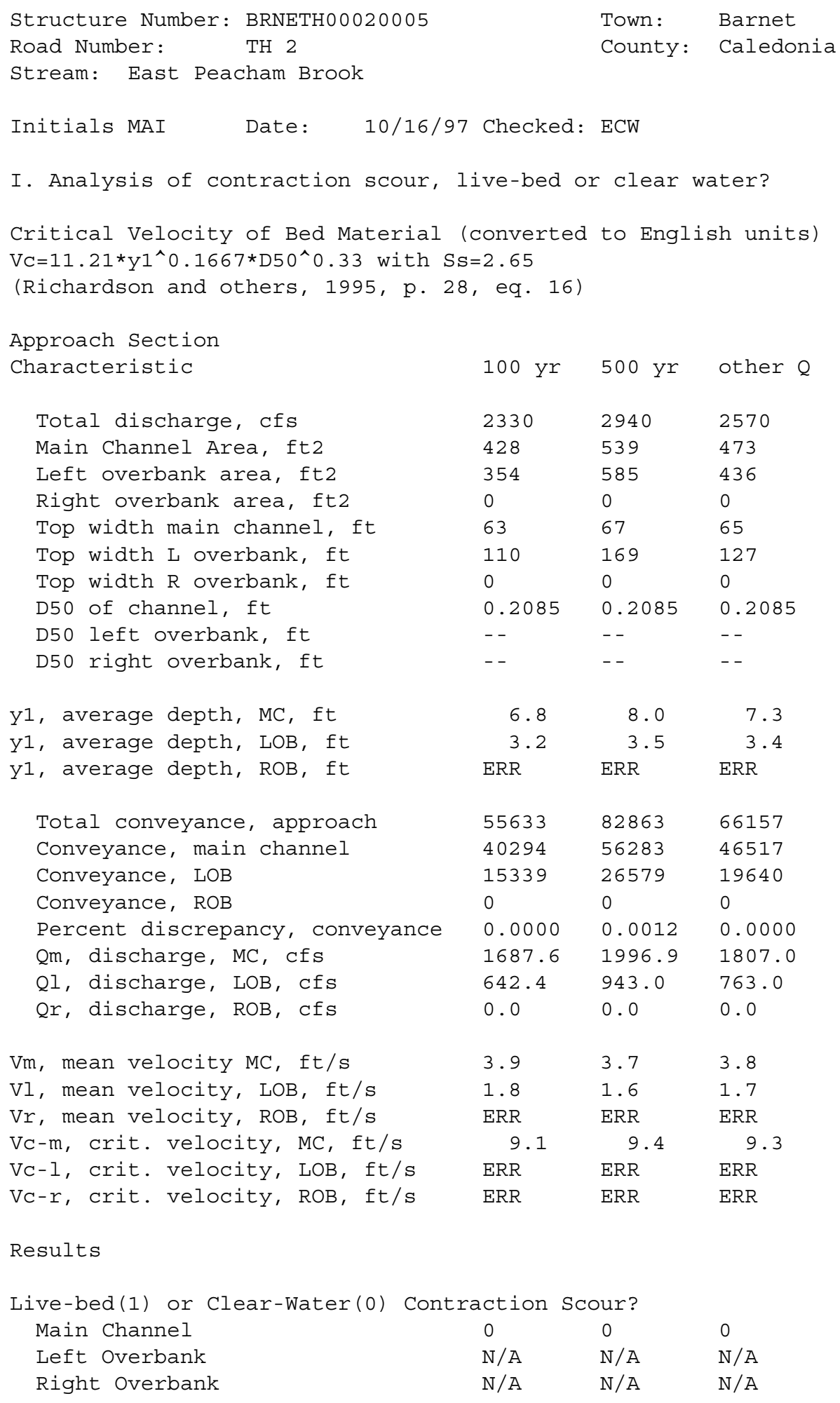


Clear water Contraction Scour in MAIN CHANNEL

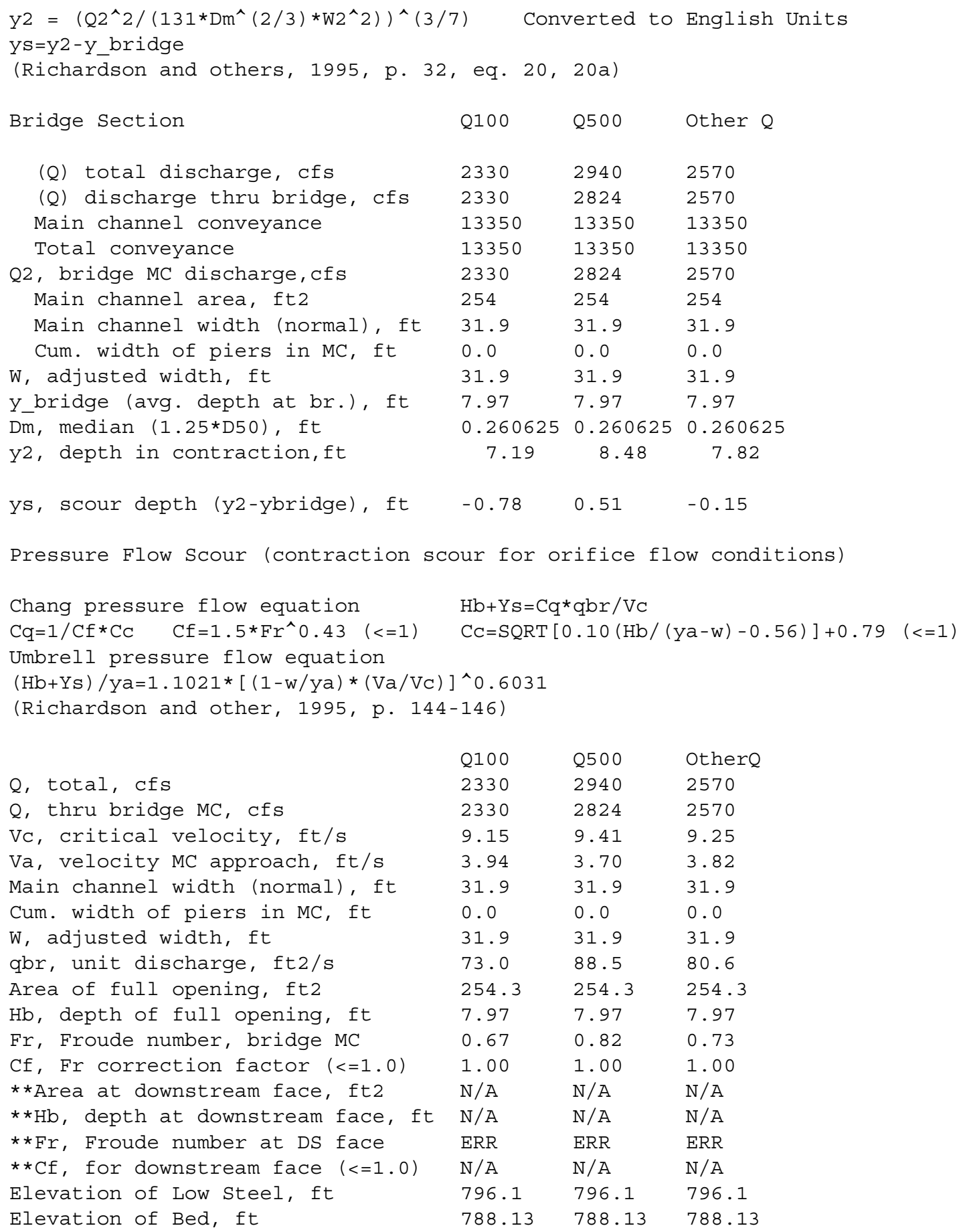




\begin{tabular}{|c|c|c|c|}
\hline Elevation of Approach, ft & 798.34 & 800.05 & 799.04 \\
\hline Friction loss, approach, ft & 0.37 & 0.38 & 0.38 \\
\hline Elevation of WS immediately US, ft & 797.97 & 799.67 & 798.66 \\
\hline ya, depth immediately US, ft & 9.84 & 11.54 & 10.53 \\
\hline Mean elevation of deck, ft & 799.68 & 799.68 & 799.68 \\
\hline w, depth of overflow, ft $(>=0)$ & 0.00 & 0.00 & 0.00 \\
\hline Cc, vert contrac correction $(<=1.0)$ & 0.95 & 0.90 & 0.93 \\
\hline$\star *$ Cc, for downstream face $(<=1.0)$ & ERR & ERR & ERR \\
\hline our $\mathrm{w} / \mathrm{Cl}$ & 0.45 & 2.43 & 1.39 \\
\hline Is, scour w/Umbrel] & -1.44 & -0.72 & -1.16 \\
\hline
\end{tabular}

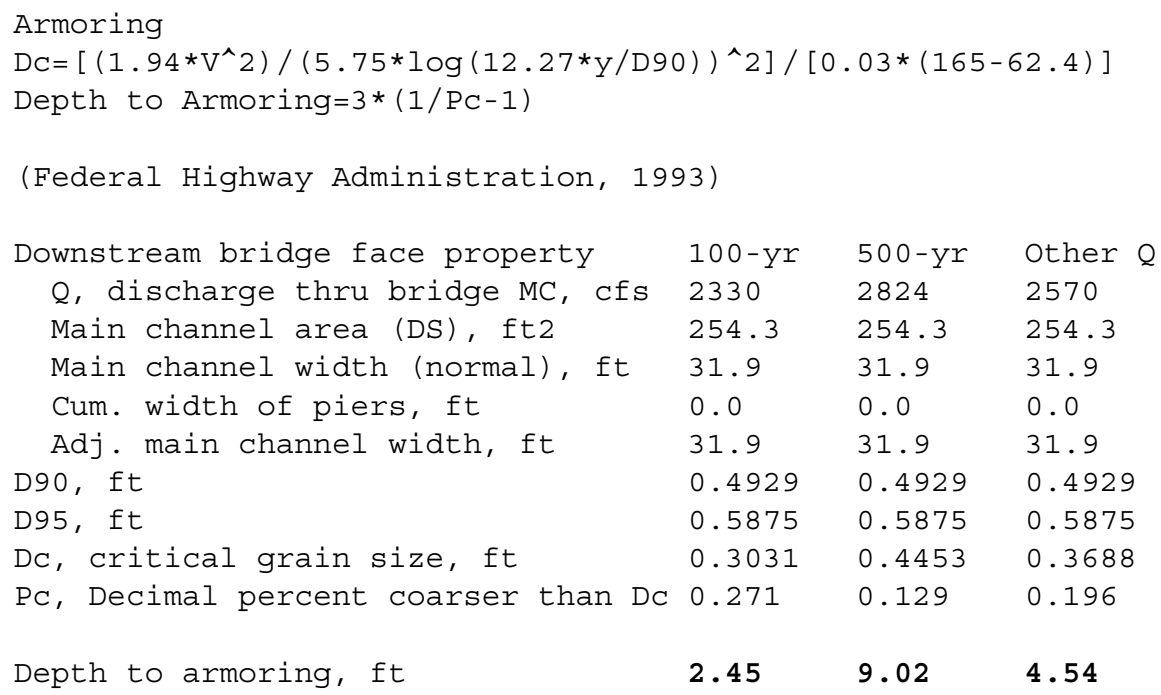




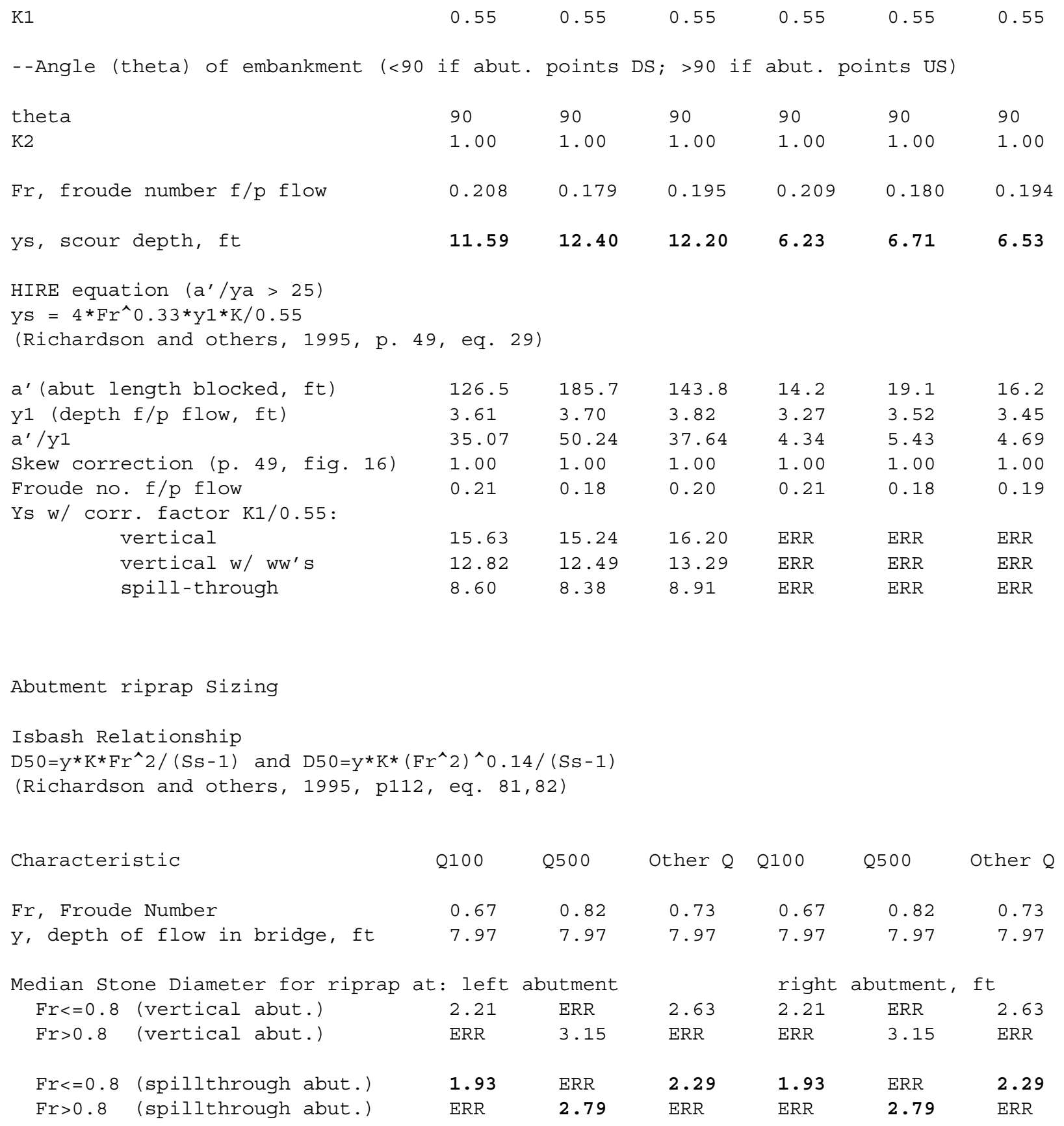


